\title{
A comparison between enriched and nonenriched enrollment randomized withdrawal trials of opioids for chronic noncancer pain
}

\author{
Andrea D Furlan MD PhD ${ }^{1,2,3}$, Luis E Chaparro MD4, Emma Irvin BA ${ }^{1}$, Angela Mailis-Gagnon MD, MSc $3,4,5$
}

AD Furlan, LE Chaparro, E Irvin, A Mailis-Gagnon. A comparison between enriched and nonenriched enrollment randomized withdrawal trials of opioids for chronic noncancer pain. Pain Res Manage 2011;16(5):337-351.

BACKGROUND: An enriched enrollment randomized withdrawal (EERW) design excludes potential participants who are nonresponders or who cannot tolerate the experimental drug before random assignment. It is unclear whether EERW design has an influence on the efficacy and safety of opioids for chronic noncancer pain (CNCP).

OBJECTIVES: The primary objective was to compare the results from EERW and non-EERW trials of opioids for CNCP. Secondary objectives were to compare weak versus strong opioids, subgroups of patients with different types of pain, and the efficacy of opiods compared with placebo versus other drugs.

METHODS: MEDLINE, EMBASE and CENTRAL were searched up to July 2009, for randomized controlled trials of any opioid for CNCP. Metaanalyses and meta-regressions were conducted to compare the results. Treatment efficacy was assessed by effect sizes (small, medium and large) and the incidence of adverse effects was assessed by a clinically relevant mean difference of $10 \%$ or greater.

RESULTS: Sixty-two randomized trials were included. In 61 trials, the duration was less than 16 weeks. There was no difference in efficacy between EERW and non-EERW trials for both pain $(\mathrm{P}=0.6)$ and function $(\mathrm{P}=0.3)$. However, EERW trials failed to detect a clinically relevant difference for nausea, vomiting, somnolence, dizziness and dry skin/itching compared with non-EERW. Opioids were more effective than placebo in patients with nociceptive pain (effect size $=0.60,95 \% \mathrm{CI} 0.49$ to 0.72 ) and neuropathic pain (effect size $=0.56,95 \%$ CI 0.38 to 0.73 ).

CONCLUSION: EERW trial designs appear not to bias the results of efficacy, but they underestimate the adverse effects. The present updated meta-analysis shows that weak and strong opioids are effective for CNCP of both nociceptive and neuropathic origin.

Key Words: Chronic pain; Enriched design; Meta-analysis; Opioids; Systematic review
Une comparaison entre des essais de retrait aléatoire
à recrutement enrichi et non enrichi des opioïdes
pour traiter les douleurs chroniques non cancéreuses

HISTORIQUE : Une méthodologie de retrait aléatoire à recrutement enrichi (RARE) exclut les participants potentiels qui ne répondent pas au traitement ou ne peuvent tolérer un médicament expérimental avant son attribution aléatoire. On ne sait pas si une méthodologie de RARE aura une influence sur l'efficacité et l'innocuité des opioïdes dans le traitement des douleurs chroniques non cancéreuses (DCNC).

OBJECTIFS : L'objectif primaire consistait à comparer les résultats des essais de RARE et des essais de retrait aléatoire à recrutement non enrichi (RARNE) des opioïdes pour traiter les DCNC. Les objectifs secondaires consistaient à comparer des opioïdes légers à des opiö̈des puissants, des sous-groupes de patients présentant divers types de douleur et l'efficacité des opioïdes par rapport à un placebo et à d'autres médicaments.

MÉTHODOLOGIE : Les auteurs ont effectué des recherches dans MEDLINE, EMBASE et CENTRAL jusqu'en juillet 2009 afin de trouver des essais aléatoires et contrôlés sur tous les types d'opioïdes utilisés pour traiter les DCNC. Ils ont effectué des méta-analyses et des méta-régressions pour comparer les résultats. Ils ont évalué l'efficacité thérapeutique par l'ampleur de l'effet (petite, moyenne ou grande) et l'incidence des effets indésirables au moyen d'une différence moyenne pertinente sur le plan clinique de $10 \%$ ou plus.

RÉSULTATS : Soixante-deux essais aléatoires étaient inclus, dont 61 s'étaient étalés sur moins de 16 semaines. On ne constatait pas de différence d'efficacité entre les essais de RARE et les essais de RARNE, tant pour les la douleur $(\mathrm{P}=0,6)$ que pour la fonction $(\mathrm{P}=0,3)$. Cependant, les essais de RARE ne permettaient pas de déceler de différence pertinente sur le plan clinique en matière de nausées, de vomissements, de somnolence, d'étourdissements et de sécheresse de la peau ou de démangeaisons par rapport aux essais de RARNE. Les opioïdes étaient plus efficaces qu'un placebo chez les patients ayant des douleurs nociceptives (ampleur de l'effet $=0,60,95 \%$ IC 0,49 à 0,72) et des douleurs névropathiques (ampleur de l'effet $=0,56,95 \%$ IC 0,38 à 0,73).

CONCLUSION : La méthodologie des essais de RARE ne semble pas biaiser les résultats d'efficacité, mais elle sous-estime les effets indésirables. La présente méta-analyse mise à jour démontre que des opioïdes légers et puissants sont efficaces pour traiter les DCNC d'origine nociceptive et névropathique.

participants or by provoking withdrawal symptoms that may confound the pain assessments. Moreover, the results of EERW-designed trials do not extrapolate well to more general populations (3).

In 2006, we published a systematic review of opioids for chronic noncancer pain (CNCP) (4). At that time, there were not many EERW trials to make a comparison possible. The primary objective of the present updated review is to compare the results between EERW and non-EERW trials of opioids for $\mathrm{CNCP}$ among the randomized trials included in the Canadian guideline for the safe and effective use of opioids for CNCP (5). Another objective is to assess the efficacy of weak versus strong opioids, in subgroups of various types of pain and type of comparison group used in the trials (placebo or other drugs). gesic effects because they lack the relevant metabolizing enzymes. However, this type of design may be biased by unblinding of the
${ }^{1}$ Institute for Work $\mathbb{E}$ Health; ${ }^{2}$ Toronto Rehabilitation Institute; ${ }^{3}$ Division of Physiatry, Department of Medicine, University of Toronto;

${ }^{4}$ Comprehensive Pain Program, Toronto Western Hospital; ${ }^{5}$ Krembil Neuroscience Centre, Toronto Western Hospital, Toronto, Ontario

Correspondence: Dr Andrea D Furlan, Institute for Work 83 Health, 481 University Avenue, Suite 800, Toronto, Ontario M5G 2 E9.

Telephone 416-927-2027 ext 2171, fax 416-927-4167, e-mail afurlan@iwh.on.ca 


\section{METHODS}

Our group published a systematic review with a meta-analysis of randomized trials of opioids for CNCP in 2006 (4). We updated the searches in MEDLINE (1960 to July 2009), EMBASE (1988 to July 2009) and CENTRAL using the OVID interface. We also reviewed the reference lists in the retrieved articles, reviews and textbooks. Search strategies used for MEDLINE and EMBASE were the same as those used in the original meta-analysis (Appendix 1 and 2, respectively) One reviewer (EI) conducted the electronic searches and entered the data into Reference Manager 11 (Thomson Reuters, USA), removing all duplicates.

Two independent reviewers (AF and LC) screened all titles and abstracts for potential studies meeting the following inclusion criteria:

- Study characteristics: Randomized controlled trials in humans published in languages that could be read by members of our team, ie, English, French, Portuguese or Spanish. Studies published only as abstracts were excluded.

- Population: CNCP defined as pain lasting more than six months including neuropathic pain conditions, nociceptive pain (osteoarthritis, rheumatoid arthritis, back and musculoskeletal pain) and fibromyalgia (considered to be a functional pain syndrome). We excluded migraines, dental pain, ischemic pain due to vascular disease and abdominal pain (ie, chronic pancreatitis, kidney stones, etc) because these entities are usually not classified as CNCP.

- Interventions: Any trial in which the opioid was given via the oral, transdermal, transmucosal or rectal route for at least seven days. We excluded head-to-head comparisons between opioids. In the present review, we classified the potency of opioids as weak (propoxyphene, codeine, tramadol and hydrocodone) or strong (oxycodone, morphine, oxymorphone, fentanyl and buprenorphine) (6).

- Outcomes: Only pain (intensity or pain relief), function and side effects were obtained. Examples of functional outcomes that could be extracted are the following: Brief Pain Inventory; Fibromyalgia Impact Questionnaire; Multidimensional Pain Inventory (physical function); Neck Disability Index; Oswestry Disability Index; Nottingham Health Profile; Pain Disability Index, Physical Disability; Roland Disability Questionnaire, Short Form (SF)-36 or SF-12 (physical functional scale); and Western Ontario and McMaster Universities Arthritis Index (WOMAC).

Hard copies of potential studies were retrieved and assessed for inclusion and risk of bias. Two independent reviewers (AF and LC) met to reach consensus on the included studies and risk of bias. When in doubt, a third reviewer was consulted (AMG). When we needed more information that was not reported in a particular trial, we contacted the corresponding author of that study.

The risk of bias in each trial was assessed using the six domains recommended by the Cochrane Collaboration (Appendix 3): sequence generation, allocation concealment, blinding, incomplete outcome data, selective outcome reporting and other sources of biases (7). Under 'other sources of bias', we included information about whether there was a relationship with the pharmaceutical industry. We extracted the following information about the relationship with the pharmaceutical industry: author affiliation with industry, funding of study by industry, industry providing the study drug or statistical analysis performed by an industry-affiliated statistician. In case of affirmative response to any of these questions, we concluded that there was a relationship with the pharmaceutical industry and a potential to introduce bias.

Meta-analyses and meta-regressions were conducted using Comprehensive Meta Analysis (Biostat, USA) software, with the standardized mean difference being the 'effect size' (ES) for pain and functional outcomes. The ES were classified into small $(\leq 0.5)$, medium $(0.5$ to $<0.8)$ and large $(\geq 0.8)$ as suggested by Cohen $(8)$. For side effects, all meta-analyses were conducted using Revman 5 (Cochrane
IMS, USA) using risk differences. Statistical heterogeneity was tested by $Q$ test $\left(\chi^{2}\right)$ reported as $I^{2}$ (higher values indicate higher heterogeneity). A clinically relevant difference of side effects was defined when the incidence was at least $10 \%$ higher in the opioid group compared with the control group (4). All meta-analyses were conducted using a random-effects model, and meta-regression was conducted using a fixed-effects model.

Subgroups were decided a priori to assess the variations in ES: weak versus strong opioids group; etiology of pain group: nociceptive, neuropathic, fibromyalgia and mixed; and comparison group: placebo and other drugs. In the present review, weak opioids were propoxyphene, codeine, tramadol and hydrocodone, and strong opioids were oxycodone, morphine, oxymorphone, fentanyl and buprenorphine (6).

\section{RESULTS}

There were 41 randomized trials included in the 2006 meta-analysis (4). The updated literature searches added 21 new trials. We found one case of triplicate publication about the same trial (9-11). A total of 62 randomized trials were included in this update $(9,12-72)$. Table 1 shows the characteristics of all included trials. Some trials are shown twice because they have multiple arms and comparisons. There were nine different opioids prescribed in these 62 trials: tramadol, codeine, propoxyphene, morphine, oxycodone, oxymorphone, methadone, transdermal buprenorphine and transdermal fentanyl.

All included trials were described as randomized; however, only $32(51.6 \%)$ were judged to be adequate. All but two trials $(28,33)$ were described as double-blinded, but only 40 trials were judged as having adequate methods of double-blinding; for example, double-dummy technique, capsule-in-capsule technique, or identical appearance of active and control medications. Two trials $(32,34)$ stated that the outcomes assessors were supposed to be blinded, but they were able to recognize the allocation of the treatments.

A total of 11,927 patients were randomized, but only 7807 participants finished the trials (4120 dropouts). In the opioid group, the average dropout rate was $35 \% ; 15 \%$ of the participants dropped out due to inadequate pain relief and $21 \%$ due to side effects (some patients dropped out for both reasons). In the control groups, the average dropout rate was 38\% (with 30\% of the dropouts due to inadequate pain relief and $10 \%$ due to side effects).

Forty-one trials had at least one author who was affiliated with the pharmaceutical industry. Ten trials were clearly not funded by pharmaceutical companies, five did not report any information about funding, and the remaining 47 were funded by the industry. In 47 trials, the drug was provided by the industry, in nine trials it was not, and this information was not reported in the remaining five trials. The statistical analysis was performed by an industry-affiliated statistician in nine trials, by someone not affiliated with the industry in 10 trials, and this was not reported in the remaining 43 trials. When the above information was combined, 54 of the 62 trials (87\%) had some type of relationship with the pharmaceutical industry.

The study duration was shorter than six weeks in 46 trials (74\%), between 11 and 16 weeks in 15 trials (24\%) and 24 weeks in one trial (2\%).

Regarding the CNCP diagnoses, $87.1 \%$ were classified as nociceptive pain (osteoarthritis, rheumatoid arthritis and back pain without radiculopathy), 9.2\% as neuropathic pain (diabetic neuropathy, postherpetic neuralgia, phantom limb pain, 'neuropathic pain' and regional cervicobrachial pain syndrome), $3.2 \%$ as fibromyalgia and $0.41 \%$ as mixed nociceptive and neuropathic pain. The average age of the included population was 58.1 years (range 40 to 71 years); $63 \%$ were female and $85 \%$ were white.

Efficacy of opioids compared with placebo (Table 2)

Opioids were compared with placebo in 47 trials. Pain was assessed in all trials, and function in 31 trials. The results showed a medium ES in favour of opioids for pain ( $E S=0.58,95 \%$ CI 0.48 to 0.67 ) and a small ES for function ( $E S=0.34,95 \%$ CI 0.25 to 0.43 ). 
TABLE 1

Characteristics of the 62 randomized trials included in the present updated systematic review (grouped by type of opioid)

\begin{tabular}{|c|c|c|}
\hline $\begin{array}{l}\text { Reference, year } \\
\text { Country, design }\end{array}$ & $\begin{array}{l}\text { Population type; } \\
\text { Randomized, n } \\
\text { (dropouts, n) }\end{array}$ & $\begin{array}{l}\text { Interventions and } \\
\text { comparison groups }\end{array}$ \\
\hline \multicolumn{3}{|c|}{ Placebo-controlled (neuropathic pain) } \\
\hline $\begin{array}{l}\text { Harati et al (30), } \\
1998\end{array}$ & $\begin{array}{l}\text { Diabetic neuropathy; } \\
131 \text { (49) }\end{array}$ & $\begin{array}{l}\text { Tramadol } 50-400 \mathrm{mg} / \mathrm{d} \\
6 \mathrm{wks}\end{array}$ \\
\hline $\begin{array}{l}\text { USA, parallel } \\
\text { (non-EERW) }\end{array}$ & & \\
\hline
\end{tabular}

$\begin{array}{lll}\begin{array}{c}\text { Sindrup et al } \\ \text { (64), 1999 }\end{array} & \begin{array}{c}\text { Polyneuropathy; } \\ 45(11)\end{array} & \begin{array}{c}\text { Tramadol 200-400 mg/d for } \\ 4 \text { wks }\end{array} \\ \begin{array}{l}\text { Germany, } \\ \text { crossover } \\ \text { (non-EERW) }\end{array} & \\ \text { Boureau et al } & \text { Postherpetic } & \text { Tramadol 100-400 mg/d for } \\ \text { (17), 2003 } & \text { neuralgia; } & 6 \text { wks } \\ \text { France, parallel } & 127(19) & \end{array}$

Norrbrink and Spinal cord injury Lundeberg (46), with neuropathic 2009

Sweden, parallel level >6 months; (non-EERW) 35 (13)
Tramadol 50 mg tid $400 \mathrm{mg} /$ day for $4 \mathrm{wks}$
Outcomes: Primary and secondary

Primary: Pain intensity* (5-point Likert scale)

Secondary: Pain relief, quality of life (Medical Outcomes Study): physical functioning*, social functioning, current health perception, psychological distress, overall role functioning, and the two overall sleep problem indexes and sleep subscales

Primary: Pain ratings* (0-10 NRS), paraesthesia and touch-evoked pain Secondary: Dynamic allodynia, rescue medication, patient's preference

Primary: Pain intensity (100 mm VAS* and 5-point NRS)

Secondary: Global improvement, quality of life (Nottingham scale) and rescue medication (paracetamol)

Primary: Present, general and worst pain. MPI subscale pain severity. Patient global impression of change

Secondary: Anxiety, global life satisfaction and sleep quality
Results (as reported in the studies)

Tramadol, at an average dose of $210 \mathrm{mg} / \mathrm{d}$, was significantly more effective than placebo. Patients on tramadol scored significantly better in physical and social functioning
(non-EERW)

Pain, paraesthesia, touch-evoked pain and allodynia were lower on tramadol than on placebo. NNT to obtain one patient with $\geq 50 \%$ pain relief was 4.3 (95\% Cl 2.4 to 20 )

Mean pain intensity was significantly lower with tramadol in both per protocol and intention-to-treat populations. No significant difference was found between groups in pain intensity on a 5-point verbal scale or in quality-of-life measurement

Significant differences in present pain, general pain and worst pain, as well as MPI favouring tramadol. Seven patients on active drug $(30 \%)$ rated an improvement, but only $4(17 \%)$ rated their pain to be much improved. One patient in the placebo group reported minimal improvement $(8 \%)$. No patients in either group reported their pain to be very much improved

$\begin{array}{ll}\text { Watson and } & \text { Postherpetic } \\ \text { Babul (69), } 1998 & \begin{array}{l}\text { neuralgia; } \\ \text { Canada, }\end{array} \\ \begin{array}{l}\text { crossover } \\ \text { (non-EERW) }\end{array} & \end{array}$

CR oxycodone $20-60 \mathrm{mg} / \mathrm{d}$ (mean $45 \mathrm{mg} / \mathrm{d}$ ) for $4 \mathrm{wks}$

Primary: Pain intensity (100 mm VAS* and 5-point categorical scale)

Secondary: Pain relief, steady pain, brief pain, skin pain, disability* (using a categorical scale: $0=$ no disability, 3 = severe disability), BDI, POMS

Watson et al (68), Diabetic neuropathy; CR oxycodone 20-80 mg/d $2003 \quad 45(3) \quad$ (mean $40 \mathrm{mg} / \mathrm{d}$ ) for $4 \mathrm{wks}$

Canada,

crossover

(non-EERW)

Gimbel et al (26), Diabetic neuropathy; CR oxycodone $20-120 \mathrm{mg} / \mathrm{d}$ 2003 159 (44) (mean $37 \mathrm{mg} / \mathrm{d}$ ) for $6 \mathrm{wks}$

USA, parallel

(non-EERW)

Huse et al (32), 2001

Phantom limb pain; SR morphine $70-300 \mathrm{mg} / \mathrm{d}$ 12 (3) (mean $120 \mathrm{mg} / \mathrm{d}$ ) for $4 \mathrm{wks}$

Germany,

crossover

(non-EERW)

Harke et al (31), Peripheral SR morphine $90 \mathrm{mg} / \mathrm{d}$ for 2001 neuropathy; $1 \mathrm{wk}$

Germany, parallel $38(3)$ (non-EERW)

Wu et al (71), 2008

USA, crossover

Postamputation pain SR morphine $15-180 \mathrm{mg} / \mathrm{d}$ 60 (25) for 6 wks
Primary: Pain intensity (100 mm VAS* and 5-point categorical scale)

Secondary: Pain relief, steady pain, brief pain, skin pain, $\mathrm{PDI}^{*}$, SF-36, pain and sleep questionnaires

Primary: Pain intensity* (0-10 NRS)

Secondary: Current and worse pain, satisfaction, BPI* (physical function score), SF-36

Primary: Pain intensity* (2 cm VAS) Secondary: PES, SDS, PRSS, WHYMPI, BSS

Pain intensity* (0-10 numeric analogue scale), and reactivation of their spinal cord stimulator

Primary: Average change in overall pain intensity from baseline to the final week of maintenance therapy using 0-10 NRS Secondary: Pain relief (0-100\%) and the interference and general activity subscales from the MPI. Side effects xycodone was significantly better for pain relief, reductions in steady pain, allodynia, paroxysmal spontaneous pain, global effectiveness, disability and masked preference

Oxycodone was significantly better for daily pain, steady pain, brief pain, skin pain, total pain and disability. NNT to obtain 1 patient with at least $50 \%$ pain relief was 2.6

Oxycodone provided more analgesia than placebo in the intention-to-treat cohort

Based on pain diary data, $42 \%$ of patients on morphine showed a pain reduction of more than $50 \%$ compared with only 1 patient in the placebo group

The differences between morphine and placebo were not significant

Morphine provided lower pain scores compared with placebo. The mean per cent pain relief during treatment with placebo and morphine was $19 \%$ and $53 \%$, respectively. NNT to obtain $50 \%$ and $33 \%$ decreases in pain intensity with morphine were 5.6 and 4.5 , respectively 
TABLE 1 - CONTINUED

Characteristics of the 62 randomized trials included in the present updated systematic review (grouped by type of opioid)

\begin{tabular}{|c|c|c|}
\hline $\begin{array}{l}\text { Reference, year } \\
\text { Country, design } \\
\end{array}$ & $\begin{array}{l}\text { Population type; } \\
\text { Randomized, n } \\
\text { (dropouts, n) }\end{array}$ & $\begin{array}{l}\text { Interventions and } \\
\text { comparison groups }\end{array}$ \\
\hline \multicolumn{3}{|c|}{ Placebo-controlled (neuropathic pain) } \\
\hline $\begin{array}{l}\text { Raja et al (52), } \\
2002 \\
\text { USA, crossover } \\
\text { (non-EERW) }\end{array}$ & $\begin{array}{l}\text { Postherpetic } \\
\text { neuralgia; } \\
76(32)\end{array}$ & $\begin{array}{l}\text { CR morphine } 15-240 \mathrm{mg} / \mathrm{d} \\
\text { (mean } 91 \mathrm{mg} / \mathrm{d} \text { ) for } 6 \mathrm{wks} \\
\text { or methadone } 15 \mathrm{mg} / \mathrm{d}\end{array}$ \\
\hline $\begin{array}{l}\text { Gilron et al (25), } \\
2005\end{array}$ & $\begin{array}{l}35 \text { diabetic } \\
\text { neuropathy and }\end{array}$ & $\begin{array}{l}\text { A. SR morphine maximum } \\
\text { tolerated for } 5 \mathrm{wks}\end{array}$ \\
\hline $\begin{array}{l}\text { Canada, } \\
\text { crossover } \\
\text { (non-EERW) }\end{array}$ & $\begin{array}{l}22 \text { postherpetic } \\
\text { neuralgia; } \\
57(16)\end{array}$ & $\begin{array}{l}\text { B. SR morphine maximum } \\
\text { tolerated combined with } \\
\text { gabapentin for } 5 \text { wks } \\
\text { C. Gabapentin maximum } \\
\text { tolerated for } 5 \text { wks }\end{array}$ \\
\hline $\begin{array}{l}\text { Khoromi et al } \\
\text { (34), } 2007 \\
\text { USA, crossover } \\
\text { (non-EERW) }\end{array}$ & $\begin{array}{l}\text { Chronic lumbar } \\
\text { radiculopathy } \\
\text { (sciatica); } \\
55(27)\end{array}$ & $\begin{array}{l}\text { A. SR morphine } 15-90 \mathrm{mg} / \mathrm{d} \\
\text { B. Nortriptyline } 25-100 \mathrm{mg} / \mathrm{d} \\
\text { C. Combination of each } \\
\text { phase: } 5+2+2 \text { wks }\end{array}$ \\
\hline $\begin{array}{l}\text { Simpson et al } \\
\text { (63), } 2007\end{array}$ & $\begin{array}{l}\text { Acute-on-chronic } \\
\text { pain; }\end{array}$ & $\begin{array}{l}\text { Fentanyl buccal tablet } \\
100-800 \mu \mathrm{g}\end{array}$ \\
\hline $\begin{array}{l}\text { USA, crossover } \\
\text { (EERW) }\end{array}$ & $79(4)$ & $\begin{array}{l}\text { Duration: } 9 \text { episodes or } \\
21 \text { days }\end{array}$ \\
\hline
\end{tabular}

Outcomes: Primary and secondary Results (as reported in the studies)

Primary: Pain intensity* (0-10 NRS) Morphine reduced pain (1.9) more than

Secondary: Pain relief, cognitive function, placebo (0.2). Pain relief was greater with $\mathrm{MPI}^{*}$ (physical functioning subscale), morphine (38\%) compared with placebo sleep, mood, global preference (11\%)

Primary: Pain intensity* (0-10 NRS) Mean pain intensity at the maximal tolerated

Secondary: SF-MPQ, maximal tolerated dose was 4.49 with placebo, 4.15 with doses, mood (BDI), SF-36 (physical gabapentin, 3.7 with morphine and 3.06 with function*), mental status (Mini-Mental) gabapentin-morphine combination. Total and global pain relief scores in SF-36 were lower with gabapentinmorphine combination than with placebo or each drug alone

Primary: Average leg pain during the 2 wks*

Secondary: Global pain relief, ODI*, BDI

None of the treatments produced significant reductions in average leg pain, or other leg or back pain scores and SF-36

Primary: Sum of pain intensity differences SPID-60 was significantly greater for (0-10 NRS) in the first 60 min (SPID-60) breakthrough pain episodes treated with Secondary: Proportion of breakthrough episodes with $33 \%$ and $50 \%$ fentanyl buccal tablets compared with improvement; time to significant pain relief, pain intensity differences, proportion of episodes with meaningful pain relief and proportion of episodes that required supplemental medication those in which placebo was administered

Placebo-controlled (nociceptive pain)

\begin{tabular}{|c|c|c|c|c|}
\hline $\begin{array}{l}\text { Roth (54), } 1998 \\
\text { USA, parallel } \\
\text { (EERW) }\end{array}$ & $\begin{array}{l}\text { Osteoarthritis (not } \\
\text { specified); } \\
42(8)\end{array}$ & $\begin{array}{l}\text { Tramadol } 200-400 \mathrm{mg} / \mathrm{d} \text { for } \\
2 \text { wks }\end{array}$ & $\begin{array}{l}\text { Primary: Time to exit from the study due } \\
\text { to therapeutic failure } \\
\text { Secondary: Severity of pain* (0-3 numeric } \\
\text { scale), ability to perform activities }\end{array}$ & $\begin{array}{l}\text { Time to exit from the study because of } \\
\text { insufficient pain relief was longer in the } \\
\text { tramadol group. Pain at rest and severity of } \\
\text { pain on motion were lower in the tramadol } \\
\text { group. No differences were noted in } \\
\text { general severity of current pain and on } \\
\text { disability to perform ADLs }\end{array}$ \\
\hline
\end{tabular}

$\begin{array}{ccc}\begin{array}{c}\text { Silverfield et al } \\ \text { (62), 2002 }\end{array} & \begin{array}{l}\text { Osteoarthritis (not } \\ \text { specified); }\end{array} & \begin{array}{l}\text { Tramadol 37.5-70 mg/d + } \\ \text { acetaminophen 325-650 }\end{array} \\ \text { USA, parallel } & 308(68) & \mathrm{mg} / \mathrm{d} \text { for } 1.5 \mathrm{wks}\end{array}$

USA, parallel $308(68)$

(non-EERW)

Emkey et al (22), 2004

USA, parallel

(non-EERW)

Fleischmann

et al (23), 2001

USA, parallel

(non-EERW)

Babul et al (13),

2004

USA, parallel

(non-EERW)

Ruoff (55), 1999

USA, parallel

(non-EERW)

Tramadol 37.5-300 mg/d + $\mathrm{mg} / \mathrm{d}$ for $13 \mathrm{wks}$ 307 (80)

Osteoarthritis knee; Tramadol 50-400 mg/d for 129 (93) 12 wks 246 (122) for 11 wks

Chronic joint pain; 465 (113)
Primary: Pain intensity* $(0-3$ numeric scale), pain relief

Secondary: SPID, WOMAC* (physical function subscale) acetaminophen 325-2600 specified);

Osteoarthritis knee; CR tramadol 100-400 mg/d
Primary: Pain intensity* (100 mm VAS)

Secondary: Pain relief, WOMAC* (physical function subscale), SF-36 survey

Primary: Pain intensity* (0-4 Likert scale) Secondary: Pain relief, WOMAC* (overall), global assessment, time to failure

Primary: Pain intensity* (100 mm VAS)

Secondary: WOMAC* (physical function subscale), CSPI

Primary: Discontinuation due to adverse effect or ineffectiveness
The addition of tramadol/acetaminophen to NSAID or COX-2 selective inhibitor therapy was effective in the treatment of osteoarthritis flare pain

Mean final VAS scores, mean final pain relief rating scores, WOMAC physical function and SF-36 role-physical measures were all significantly better with tramadol/ acetaminophen than with placebo

Mean final pain intensity score, and all secondary outcomes were significantly better in the tramadol group than in the placebo group

Tramadol resulted in significant improvements in pain, stiffness, physical function, global status and sleep

40 patients $(30.8 \%$ of group taking $200 \mathrm{mg} / \mathrm{d}$ from day 1) reached the primary end point; 31 patients (24.0\% from day 4$) ; 20$ patients (15.2\% from day 10 ); and 3 patients (4.4\% of placebo group)
B. Tramadol starting at $50 \mathrm{mg} / \mathrm{d}$ and reaching 200 $\mathrm{mg} / \mathrm{d}$ on day 4

C. Tramadol starting at $50 \mathrm{mg} / \mathrm{d}$ and reaching $200 \mathrm{mg} / \mathrm{d}$ on day 10

Duration of treatment: 2 wks 
TABLE 1 - CONTINUED

Characteristics of the 62 randomized trials included in the present updated systematic review (grouped by type of opioid)

\begin{tabular}{|c|c|c|c|}
\hline $\begin{array}{l}\text { Reference, year } \\
\text { Country, design }\end{array}$ & $\begin{array}{l}\text { Population type; } \\
\text { Randomized, n } \\
\text { (dropouts, n) }\end{array}$ & $\begin{array}{l}\text { Interventions and } \\
\text { comparison groups }\end{array}$ & Outcomes: Primary and secondary \\
\hline \multicolumn{4}{|c|}{ Placebo-controlled (nociceptive pain) } \\
\hline $\begin{array}{l}\text { Schnitzer et al } \\
\text { (60), } 1999 \\
\text { USA, parallel } \\
\text { (EERW) }\end{array}$ & $\begin{array}{l}\text { Osteoarthritis knee; } \\
240 \text { (4) }\end{array}$ & $\begin{array}{l}\text { Tramadol } 200 \mathrm{mg} / \mathrm{d}+ \\
\text { naproxen } 750 \mathrm{mg} / \mathrm{d} \text { reduced } \\
\text { by } 250 \mathrm{mg} / \mathrm{d} \text { every } 2 \text { wks } \\
\text { Duration total: } 8 \text { wks }\end{array}$ & $\begin{array}{l}\text { Primary: Minimum effective naproxen } \\
\text { dose }\end{array}$ \\
\hline $\begin{array}{l}\text { Schnitzer et al } \\
\text { (59), } 2000 \\
\text { USA, parallel } \\
\text { (EERW) }\end{array}$ & $\begin{array}{l}\text { Low-back pain; } \\
254 \text { (22) }\end{array}$ & $\begin{array}{l}\text { Tramadol } 200-400 \mathrm{mg} / \mathrm{d} \\
\text { (mean } 242 \mathrm{mg} / \mathrm{d} \text { ) for } 4 \mathrm{wks}\end{array}$ & $\begin{array}{l}\text { Primary: Time to exit the double-blind tr } \\
\text { Secondary: Pain intensity* }(10 \mathrm{~cm} \text { VAS) } \\
\text { pain relief, SF-MPQ, RDQ* }\end{array}$ \\
\hline $\begin{array}{l}\text { Ruoff et al (56), } \\
2003 \\
\text { USA, parallel } \\
\text { (non-EERW) }\end{array}$ & $\begin{array}{l}\text { Low-back pain; } \\
322 \text { (157) }\end{array}$ & $\begin{array}{l}\text { Tramadol 37.5-300 mg/d } \\
(\text { mean } 157.5 \mathrm{mg} / \mathrm{d})+ \\
\text { acetaminophen } 325-2600 \\
\text { mg/d for } 13 \mathrm{wks}\end{array}$ & $\begin{array}{l}\text { Primary: Pain intensity* (100 mm VAS) } \\
\text { Secondary: PRRS, SF-MPQ, RDQ*, } \\
\text { SF-36 }\end{array}$ \\
\hline $\begin{array}{l}\text { Peloso et al (49), } \\
2004 \\
\text { Canada, parallel } \\
\text { (non-EERW) }\end{array}$ & $\begin{array}{l}\text { Low-back pain; } \\
338 \text { (191) }\end{array}$ & $\begin{array}{l}\text { Tramadol 37.5-300 mg/d } \\
\text { (mean } 158 \mathrm{mg} / \mathrm{d})+ \\
\text { acetaminophen } 325-2600 \\
\text { mg/d for } 91 \text { days }\end{array}$ & $\begin{array}{l}\text { Primary: Pain intensity* (100 mm VAS) } \\
\text { Secondary: PRRS, SF-MPQ, SF-36, } \\
\text { RDQ*, overall medication assessment }\end{array}$ \\
\hline
\end{tabular}

Vorsanger et al (67), 2008

Chronic low-back pain;

USA and Canada, $386(145)$ parallel (EERW)

\section{A. CR tramadol $300 \mathrm{mg} / \mathrm{d}^{*}$ for Primary: Pain intensity VAS since the 12 wks \\ previous visit}

B. CR tramadol $200 \mathrm{mg} / \mathrm{d}$ for 12 wks
Secondary: Current pain intensity VAS*, global assessment of study medication, Roland Disability Index*, and overall sleep quality

Burch et al (18), Osteoarthritis knee; Tramadol (200-300 mg/d) for Primary: Pain intensity (11-point NRS)*

$2007 \quad 646(155)$

Canada, parallel (EERW)

Kosinski et al (9), Osteoarthritis (knee A. ER tramadol $100 \mathrm{mg} / \mathrm{d}$ for 2007; Gana et or hip), ACR 12 wks

al (10), 2006; functional class $\quad$ B. ER tramadol $200 \mathrm{mg} / \mathrm{d}$ for Schein et al I-III;

(11), $2008 \quad 1020$ (462)

USA, parallel

(non-EERW)

Lee et al (39), 2006

Korea, parallel (non-EERW)

Thorne et al (65), Osteoarthritis knee 2008

Canada,

crossover (non-EERW)

Boureau and Rheumatoid Boccard (16), 1991 arthritis; 40 (2)

France, parallel (non-EERW)

\section{Rheumatoid arthritis pain inadequately} controlled by NSAIDs and DMARD; 277 (10) or hip;

CR tramadol: 150-300 mg for 8 wks

$$
12 \text { wks }
$$

C. ER tramadol $300 \mathrm{mg} / \mathrm{d}$ for 12 wks

D. ER tramadol $400 \mathrm{mg} / \mathrm{d}$ for 12 wks

Tramadol $37.5 \mathrm{mg} / \mathrm{d}$ plus acetaminophen $325 \mathrm{mg} / \mathrm{d}$ for $1 \mathrm{wk}$

$100(25)$
Secondary: Patient and physician global impression of change

Primary: Pain intensity (100 mm VAS)* Secondary: Chronic pain sleep inventory
Results (as reported in the studies)

The addition of tramadol enabled a significant reduction in the dosage of naproxen without compromising pain relief

Discontinuation rate due to therapeutic failure was $20.7 \%$ in the tramadol group and $51.3 \%$ in the placebo group. Pain scores, SF-MPQ and RDQ were significantly better in the tramadol group Pain intensity, final PRRS scores, RDQ scores and many subscales of SF-MPQ and SF-36 were significantly better with tramadol than with placebo

VAS, pain relief scores, RDQ, physical-related subcategories of MPQ and SF-36 were significantly better for tramadol/ acetaminophen than for placebo. More patients rated tramadol/acetaminophen as 'very good' or 'good' compared with placebo The placebo group had greater mean deterioration for pain intensity since the previous visit (+12.2 $\mathrm{mm}$ ) compared with patients who continued to receive tramadol $300 \mathrm{mg}(+5.2 \mathrm{~mm})$ and patients whose tramadol dose was reduced to $200 \mathrm{mg}$ $(+7.8 \mathrm{~mm})$. There were better responses in the tramadol groups versus placebo for the secondary variables

The absolute mean $( \pm S D$ ) reduction in pain intensity in the tramadol group was $3.0 \pm 2.1$. There was a statistically significant difference from placebo

Mean pain reduction at 12 wks was $-0.4 \mathrm{~mm}$ and $-21.5 \mathrm{~mm}$ for tramadol ER and placebo, respectively $(\mathrm{P}<0.001)$

Primary: Mean daily pain relief score on a Pain relief scores and pain intensity scores 6-point scale

Secondary: Mean daily pain intensity (100 mm VAS)*, pain intensity at day 7 , subjects' and investigators' mean overall assessment, physical function* (Health Assessment Questionnaire)

Primary: Daily diary pain intensity score* Secondary: WOMAC pain and physical function* were significantly better in the tramadol/ acetaminophen group than in the placebo group. Physical function did not differ significantly between tramadol/ acetaminophen and placebo

Tramadol resulted in significantly lower pain intensity (37.4 \pm 23.9$)$ compared with placebo (45.1 \pm 24.3$)$. WOMAC index subscale score for pain and physical function were significantly better with tramadol than with placebo

Analgesic efficacy was significantly better with codeine/acetaminophen than with placebo for all criteria except the number of awakenings 
TABLE 1 - CONTINUED

Characteristics of the 62 randomized trials included in the present updated systematic review (grouped by type of opioid)

\begin{tabular}{|c|c|c|c|c|}
\hline $\begin{array}{l}\text { Reference, year } \\
\text { Country, design }\end{array}$ & $\begin{array}{l}\text { Population type; } \\
\text { Randomized, n } \\
\text { (dropouts, n) }\end{array}$ & $\begin{array}{l}\text { Interventions and } \\
\text { comparison groups }\end{array}$ & Outcomes: Primary and secondary & Results (as reported in the studies) \\
\hline \multicolumn{5}{|c|}{ Placebo-controlled (nociceptive pain) } \\
\hline $\begin{array}{l}\text { Arkinstall et al } \\
\text { (12), } 1995\end{array}$ & $\begin{array}{l}\text { Mixed nociceptive; } \\
46 \text { (16) }\end{array}$ & $\begin{array}{l}\text { CR codeine } 200-400 \mathrm{mg} / \mathrm{d} \\
\text { for } 1 \mathrm{wk}\end{array}$ & $\begin{array}{l}\text { Primary: Pain intensity (100 mm VAS* } \\
\text { and 5-point categorical scale) }\end{array}$ & $\begin{array}{l}\text { The codeine group was significantly better } \\
\text { on overall pain intensity }(35 \pm 18) \text { than }\end{array}$ \\
\hline $\begin{array}{l}\text { Canada, } \\
\text { crossover } \\
\text { (non-EERW) }\end{array}$ & & & $\begin{array}{l}\text { Secondary: Rescue acetaminophen + } \\
\text { codeine consumption, } \mathrm{PDI}{ }^{*} \text { and patients' } \\
\text { and investigators' treatment preferences }\end{array}$ & $\begin{array}{l}\text { placebo (49 } \pm 16) \text {, and on categorical pain } \\
\text { intensity and pain scores according to day } \\
\text { and time of day. Daily rescue analgesic } \\
\text { consumption was lower in the codeine } \\
\text { group. Disability was lower in the codeine } \\
\text { group compared with placebo }\end{array}$ \\
\hline $\begin{array}{l}\text { Peloso et al (50), } \\
2000\end{array}$ & \multirow{2}{*}{$\begin{array}{l}\text { Osteoarthritis hip or } \\
\text { knee; } \\
103(37)\end{array}$} & \multirow[t]{2}{*}{$\begin{array}{l}\text { CR codeine } 100-400 \mathrm{mg} / \mathrm{d} \\
\text { for } 4 \text { wks }\end{array}$} & $\begin{array}{l}\text { Primary: WOMAC - pain intensity* } \\
\text { (0-500 VAS) }\end{array}$ & $\begin{array}{l}\text { All variables in the efficacy analysis indicated } \\
\text { superiority of codeine over placebo. The }\end{array}$ \\
\hline $\begin{array}{l}\text { Canada, parallel } \\
\text { (non-EERW) }\end{array}$ & & & $\begin{array}{l}\text { Secondary: WOMAC* (stiffness and } \\
\text { physical function), sleep, global } \\
\text { assessment }\end{array}$ & $\begin{array}{l}\text { WOMAC improved } 44.8 \% \text { over baseline in } \\
\text { the codeine group compared with } 12.3 \% \text { in } \\
\text { the placebo group }\end{array}$ \\
\hline $\begin{array}{l}\text { Roth et al (53), } \\
2000\end{array}$ & $\begin{array}{l}\text { Osteoarthritis; } \\
133(70)\end{array}$ & $\begin{array}{l}\text { A. CR oxycodone } 20 \mathrm{mg} / \mathrm{d} \\
\text { for } 2 \text { wks* }^{*}\end{array}$ & $\begin{array}{l}\text { Primary: Pain intensity* (4-point NRS) } \\
\text { Secondary: Quality of sleep, BPI, }\end{array}$ & $\begin{array}{l}\text { Oxycodone was superior to placebo in } \\
\text { reducing pain intensity and the interference }\end{array}$ \\
\hline $\begin{array}{l}\text { USA, parallel } \\
\text { (non-EERW) }\end{array}$ & & $\begin{array}{l}\text { B. CR oxycodone } 40 \mathrm{mg} / \mathrm{d} \\
\text { for } 2 \text { wks }\end{array}$ & $\begin{array}{l}\text { interference of pain on key functional } \\
\text { activities }\end{array}$ & $\begin{array}{l}\text { of pain with mood, sleep and enjoyment of } \\
\text { life }\end{array}$ \\
\hline
\end{tabular}

(non-EERW)

Caldwell et al

(20), 1999

Osteoarthritis;

USA, parallel

107 (36)

(EERW)

Webster et al

(70), 2006

USA, parallel

(non-EERW)

Low-back pain;

719 (391)

for 2 wks

\section{activities}

A. IR oxycodone $20 \mathrm{mg} / \mathrm{d}+\quad$ Primary: Pain intensity* (4-point NRS) acetaminophen $1300 \mathrm{mg} / \mathrm{d}$ Secondary: Global measure of sleep for $4 w_{k s}^{*}$

B. CR oxycodone $20 \mathrm{mg} / \mathrm{d}$ for 4 wks

A. Oxycodone 10-80 mg/d Primary: 11-point numerical diary pain once daily* intensity scale*

B. Oxycodone 10-80 mg/d + Secondary: SF-12, ODI*, quality of ultra-low dose naltrexone analgesia, global assessment of study once daily

C. Oxycodone $10-80 \mathrm{mg} / \mathrm{d}+$ ultra-low dose naltrexone twice daily

Duration: 12 wks

Markenson et al Osteoarthritis;

CR oxycodone 10-120 mg/d Primary: BPI average pain intensity*, (mean $57 \mathrm{mg} / \mathrm{d}$ ) for $12 \mathrm{wks}$

(42), 2005 109 (73)

USA, parallel (non-EERW)

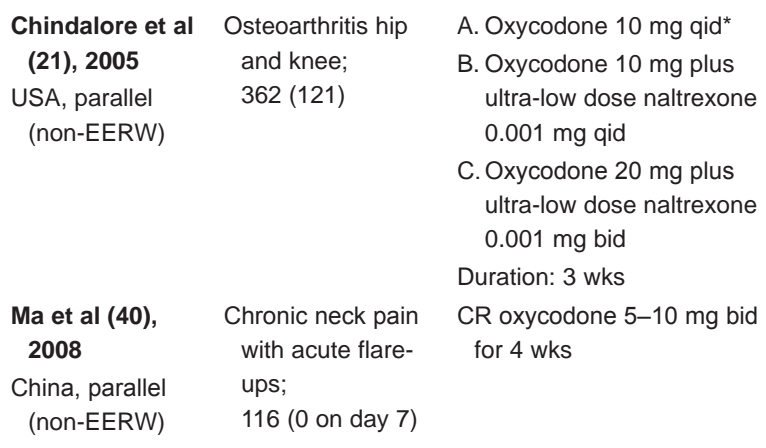

WOMAC scores at days 30 and 60 , the number of patients who discontinued the study due to inadequate pain control

Secondary: BPI (pain interference and function), WOMAC, PGI, time to stable dosing, percentage of patients achieving stable dosing within 30 days, average daily dose at completion of initial titration, patient satisfaction, average and current pain intensity from pain diaries

Primary: Pain intensity measured by 11-point NRS*

Secondary: Quality of analgesia, pain control, global assessment of study drug, SF-12, WOMAC

Pain intensity and quality of sleep were significantly improved in both active groups compared with the placebo group

All active treatment groups were significantly better than placebo on measures of pain reduction, physical component score of the SF-12 and ODI

Oxycodone was significantly superior to placebo in decreasing average pain intensity and in reducing pain-induced interference with general activity, walking ability (except at day 30) and normal work, as well as mood, sleep, relations with people (at days 60 and 90) and enjoyment in life. Daily functioning, as measured by WOMAC, was also significantly improved in the oxycodone group. In the placebo group, a significantly greater percentage of patients discontinued due to inadequate pain control

Although oxycodone was significantly better than placebo at wk 1, this treatment was not different from placebo at later time points. Oxycodone was significantly better than placebo on the pain subscale, the physical function scale and the WOMAC total score, but at wk 1 only

Primary and secondary: Frequency of pain episodes, pain intensity* (VAS), quality of life (QOL)*, quality of sleep (QOS), side effects, withdrawal symptoms, SF-36, performance status, patient satisfaction

Results were extracted for the 7-day measurement. The frequency of pain episodes and VAS were decreased significantly with oxycodone. Improvements in QOL and QOS were significant on day 3 after treatment with oxycodone. Most domains of SF-36 were improved in the treated patients at end of study 
TABLE 1 - CONTINUED

Characteristics of the 62 randomized trials included in the present updated systematic review (grouped by type of opioid)

\begin{tabular}{|c|c|c|c|c|}
\hline $\begin{array}{l}\text { Reference, year } \\
\text { Country, design }\end{array}$ & $\begin{array}{l}\text { Population type; } \\
\text { Randomized, n } \\
\text { (dropouts, n) }\end{array}$ & $\begin{array}{l}\text { Interventions and } \\
\text { comparison groups }\end{array}$ & Outcomes: Primary and secondary & Results (as reported in the studies) \\
\hline \multicolumn{5}{|c|}{ Placebo-controlled (nociceptive pain) } \\
\hline $\begin{array}{l}\text { Caldwell et al } \\
\text { (19), } 2002 \\
\text { USA, parallel } \\
\text { (non-EERW) }\end{array}$ & $\begin{array}{l}\text { Osteoarthritis hip } \\
\text { and/or knee; } \\
295 \text { (111) }\end{array}$ & $\begin{array}{l}\text { A. ER morphine } 30 \mathrm{mg} / \mathrm{d} \\
\text { (morning) for } 4 \mathrm{wks}^{*} \\
\text { B. ER morphine } 30 \mathrm{mg} / \mathrm{d} \\
\text { (evening) for } 4 \mathrm{wks} \\
\text { C. CR morphine } 15 \mathrm{mg} \\
\text { twice/d for } 4 \mathrm{wks}\end{array}$ & $\begin{array}{l}\text { Primary: WOMAC osteoarthritis index pain } \\
(0-500) \text { and overall arthritis pain } \\
\text { intensity* (0-100) } \\
\text { Secondary: WOMAC stiffness and } \\
\text { physical function* (0-1700) }\end{array}$ & $\begin{array}{l}\text { Morphine once daily and morphine } \\
\text { twice daily both reduced pain and improved } \\
\text { several sleep measures compared with } \\
\text { placebo. Analgesic efficacy was } \\
\text { comparable between once daily and twice } \\
\text { daily formulations }\end{array}$ \\
\hline $\begin{array}{l}\text { Moran (44), } 1991 \\
\text { United Kingdom, } \\
\text { crossover } \\
\text { (non-EERW) }\end{array}$ & $\begin{array}{l}\text { Rheumatoid } \\
\text { arthritis; } \\
20 \text { (16) }\end{array}$ & $\begin{array}{l}\text { CR morphine } 20-120 \mathrm{mg} / \mathrm{d} \\
\text { for } 2 \text { wks }\end{array}$ & $\begin{array}{l}\text { Primary: Pain intensity* (100 mm VAS) } \\
\text { Secondary: Fries Index Health } \\
\text { Assessment Questionnaire*, RS, GSS }\end{array}$ & $\begin{array}{l}\text { Although only } 4 \text { patients completed the } \\
\text { study, results showed a significant } \\
\text { improvement in pain in those taking } \\
\text { morphine }\end{array}$ \\
\hline $\begin{array}{l}\text { Moulin et al (45), } \\
1996 \\
\text { Canada, } \\
\text { crossover } \\
\text { (non-EERW) }\end{array}$ & $\begin{array}{l}\text { Musculoskeletal } \\
\text { pain; } \\
61(18)\end{array}$ & $\begin{array}{l}\text { SR morphine } 30-120 \mathrm{mg} / \mathrm{d} \\
\quad(\mathrm{mean} 83.5 \mathrm{mg} / \mathrm{d}) \text { for } 6 \mathrm{wks}\end{array}$ & $\begin{array}{l}\text { Primary: Pain intensity* }(10 \mathrm{~cm} \text { VAS) } \\
\text { Secondary: Pain relief, MPQ, drug liking, } \\
\text { rescue medication, SCL-90, POMS, SIP, } \\
\text { PDI* }^{*} \text { HSCS, patient's preferences }\end{array}$ & $\begin{array}{l}\text { On VAS of pain, the morphine group showed } \\
\text { a reduction in pain intensity relative to } \\
\text { placebo in period I, and this group also } \\
\text { fared better in a crossover analysis of the } \\
\text { sum of pain intensity differences from } \\
\text { baseline. No other significant differences } \\
\text { were detected }\end{array}$ \\
\hline $\begin{array}{l}\text { Hale et al (29), } \\
2007 \\
\text { USA, parallel } \\
\text { (EERW) }\end{array}$ & $\begin{array}{l}\text { Low-back pain; } \\
143 \text { (76) }\end{array}$ & $\begin{array}{l}\text { ER oxymorphone } \\
20-260 \mathrm{mg} / \mathrm{d} \text { (mean } \\
87.2 \mathrm{mg} / \mathrm{d} \text {, median } 60 \mathrm{mg} / \mathrm{d} \text { ) } \\
\text { for } 12 \mathrm{wks}\end{array}$ & $\begin{array}{l}\text { Primary: Change in average pain intensity } \\
\text { (VAS) from baseline to final study visit* } \\
\text { Secondary: } 24 \text { h pain intensity, use of } \\
\text { medication, patients' and physicians' } \\
\text { overall satisfaction }\end{array}$ & $\begin{array}{l}\text { Pain intensity increased significantly more } \\
\text { for patients randomly assigned to placebo } \\
\text { than for patients who continued their } \\
\text { stabilized dose of oxymorphone. The } \\
\text { increase from baseline to final visit was } \\
31.6 \mathrm{~mm} \text { with placebo and } 8.7 \mathrm{~mm} \text { with } \\
\text { oxymorphone }\end{array}$ \\
\hline $\begin{array}{l}\text { Matsumoto et al } \\
\text { (43), } 2005 \\
\text { USA, parallel } \\
\text { (non-EERW) }\end{array}$ & $\begin{array}{l}\text { Osteoarthritis; } \\
491 \text { (222) }\end{array}$ & $\begin{array}{l}\text { A. ER oxymorphone } 40 \mathrm{mg} \\
\text { bid* }^{*} \\
\text { B. ER oxymorphone } 20 \mathrm{mg} \\
\text { bid } \\
\text { C. CR oxycodone } 20 \mathrm{mg} \text { bid } \\
\text { Duration: } 4 \text { wks }\end{array}$ & $\begin{array}{l}\text { Primary: Pain intensity (VAS) at wk } 3 \\
\text { Secondary: Pain intensity from pain diary } \\
\text { at wk } 4^{*} \text {, WOMAC, patient and physician } \\
\text { global assessments, dropouts due to lack } \\
\text { of analgesia, sleep assessment, quality } \\
\text { of life physical* and mental components } \\
\text { (SF-36) }\end{array}$ & $\begin{array}{l}\text { The primary end point showed a significant } \\
\text { difference in favour of oxymorphone over } \\
\text { placebo. Compared with placebo, both } \\
\text { oxymorphone } 20 \mathrm{mg} \text { and } 40 \mathrm{mg} \text { produced } \\
\text { greater reductions in the WOMAC } \\
\text { subscales at wks } 3 \text { and } 4\end{array}$ \\
\hline
\end{tabular}

Kivitz et al (35), Osteoarthritis hip or A. ER oxymorphone $10 \mathrm{mg}$ 2006 knee; bid for 2 wks

USA, parallel $\quad 370(172)$ (non-EERW)

B. ER oxymorphone $20 \mathrm{mg}$ bid for $1 \mathrm{wk}$, then $40 \mathrm{mg}$ bid for $1 \mathrm{wk}$

C. ER oxymorphone $20 \mathrm{mg}$ bid for $1 \mathrm{wk}$, then $50 \mathrm{mg}$ bid for $1 w^{*}$

Zautra et al (72), Moderate to severe A. CR oxycodone $10 \mathrm{mg}$ bid 2005 for 2 wks

USA, paralle pain due to (non-EERW) osteoarthritis; 107 (71)

They reported the results at 2 wks, but the study lasted for 3 months (SF-36)

Primary: Arthritis pain intensity from VAS at wks 1 and $2^{*}$

Secondary: WOMAC*, SF-36, Chronic Pain Sleep Inventory (CPSI), vital signs, clinical laboratory parameters and adverse events

Oxymorphone ER administered twice daily for 2 wks produced dose-related reductions in arthritis pain intensity and improvements in physical function

Primary: Average 24 h pain rating* (average of 12 daily reports was used for the 2 wks post-test score on pain)

Secondary: Positive and negative Watson's scale for affect. Vanderbilt multidimensional pain coping inventory. Coping efficacy and arthritis helplessness

Primary: Electronic pain diary, 0-120 min after pain crisis. SPID-60 was the sum of pain intensity differences for the first $60 \mathrm{~min}$

Secondary: Proportion of breakthrough pain episodes with improvement $>33 \%$ and $50 \%$, pain relief at each posttreatment time point, proportion of episodes in which meaningful pain relief was obtained, time to meaningful pain relief, and proportion of episodes that required the use of supplemental medication 
TABLE 1 - CONTINUED

Characteristics of the 62 randomized trials included in the present updated systematic review (grouped by type of opioid)

\begin{tabular}{|c|c|c|c|c|}
\hline $\begin{array}{l}\text { Reference, year } \\
\text { Country, design }\end{array}$ & $\begin{array}{l}\text { Population type; } \\
\text { Randomized, n } \\
\text { (dropouts, n) }\end{array}$ & $\begin{array}{l}\text { Interventions and } \\
\text { comparison groups }\end{array}$ & Outcomes: Primary and secondary & Results (as reported in the studies) \\
\hline \multicolumn{5}{|c|}{ Placebo-controlled (nociceptive pain) } \\
\hline $\begin{array}{l}\text { Langford et al } \\
\text { (38), } 2006 \\
\text { Multicentre in } \\
\text { Europe, parallel } \\
\text { (non-EERW) }\end{array}$ & $\begin{array}{l}\text { Osteoarthritis hip } \\
\text { and knee. } \\
\text { Moderate to } \\
\text { severe pain; } \\
416 \text { (217) }\end{array}$ & $\begin{array}{l}\text { Transdermal fentanyl (TDF) } \\
(25-100 \mu \mathrm{g}) \text { for } 6 \mathrm{wks}\end{array}$ & $\begin{array}{l}\text { Primary: Pain relief* (average AUC of the } \\
\text { VAS scores over time) } \\
\text { Secondary: WOMAC* score and its } \\
\text { components }\end{array}$ & $\begin{array}{l}\text { Transdermal fentanyl provided significantly } \\
\text { better pain relief than placebo, as } \\
\text { demonstrated by the primary AUC for VAS } \\
\text { scores: }-20 \text { in the TDF group versus }-14.6 \\
\text { in the placebo group. TDF was also } \\
\text { associated with significantly better overall } \\
\text { WOMAC scores and pain scores }\end{array}$ \\
\hline $\begin{array}{l}\text { Landau et al (37), } \\
2007 \\
\text { UK and USA, } \\
\text { parallel (EERW) }\end{array}$ & $\begin{array}{l}\text { Noncancer pain } \\
\text { (49\% low back); } \\
267 \text { (12) }\end{array}$ & $\begin{array}{l}\text { Buprenorphine transdermal } \\
\text { (5-20 mg) for } 2 \mathrm{wks}\end{array}$ & $\begin{array}{l}\text { Primary: Proportion of subjects with } \\
\text { ineffective treatment* } \\
\text { Secondary: Time to ineffective treatment, } \\
\text { proportion of subjects who reached } \\
\text { ineffective treatment or discontinued for } \\
\text { any reason, amount of escape } \\
\text { medication used }\end{array}$ & $\begin{array}{l}\text { The proportion with ineffective treatment was } \\
\text { lower in the buprenorphine group than in } \\
\text { the placebo group ( } 51.2 \% \text { versus } 65 \%) \text {. } \\
\text { The odds of ineffective treatment were } \\
1.79 \text { times greater for placebo than for } \\
\text { buprenorphine }\end{array}$ \\
\hline
\end{tabular}

Placebo-controlled (fibromyalgia pain)

\begin{tabular}{|c|c|c|c|c|}
\hline $\begin{array}{l}\text { Russell et al (57), } \\
2000 \\
\text { USA, parallel } \\
\text { (EERW) }\end{array}$ & $\begin{array}{l}\text { Fibromyalgia; } \\
69 \text { (1) }\end{array}$ & $\begin{array}{l}\text { Tramadol } 50-400 \mathrm{mg} / \mathrm{d} \text { for } \\
6 \mathrm{wks}\end{array}$ & $\begin{array}{l}\text { Primary: Number of patients exiting due } \\
\text { to inadequate pain relief } \\
\text { Secondary: Pain intensity* (10 cm VAS), } \\
\text { pain relief, tender-point count, myalgic } \\
\text { score, FMIQ* }(0-100)\end{array}$ & $\begin{array}{l}20(57.1 \%) \text { patients in the tramadol group } \\
\text { successfully completed the double-blind } \\
\text { phase compared with } 9(27 \%) \text { in the } \\
\text { placebo group }\end{array}$ \\
\hline $\begin{array}{l}\text { Bennett et al } \\
\text { (15), } 2003 \\
\text { USA, parallel } \\
\text { (non-EERW) }\end{array}$ & $\begin{array}{l}\text { Fibromyalgia; } \\
315 \text { (177) }\end{array}$ & $\begin{array}{l}\text { Tramadol } 37.5-300 \mathrm{mg} / \mathrm{d}+ \\
\text { acetaminophen } \\
325-2600 \mathrm{mg} / \mathrm{d} \text { for } 11.5 \\
\text { wks }\end{array}$ & $\begin{array}{l}\text { Primary: Cumulative time of } \\
\text { discontinuation due to lack of efficacy } \\
\text { Secondary: Pain intensity* (100 mm VAS), } \\
\text { pain relief, tender-point count, myalgic } \\
\text { score, FMIQ*, SF-36,12-SQ }\end{array}$ & $\begin{array}{l}\text { Discontinuation was less common in the } \\
\text { tramadol group }(48 \%) \text { compared with the } \\
\text { placebo group }(62 \%) \text {. Tramadol-treated } \\
\text { patients also had significantly less pain at } \\
\text { the end of the study, better pain relief and } \\
\text { better FMIQ scores }\end{array}$ \\
\hline
\end{tabular}

Placebo-controlled (mixed pain)

\begin{tabular}{|c|c|c|c|c|}
\hline $\begin{array}{l}\text { Maier et al (41), } \\
2002 \\
\text { Germany, } \\
\text { crossover } \\
\text { (non-EERW) }\end{array}$ & $\begin{array}{l}\text { Neuropathic }(67 \%) \\
\text { and nociceptive } \\
(32 \%) \text {; } \\
49(13)\end{array}$ & $\begin{array}{l}\text { SR morphine } 10-180 \mathrm{mg} / \mathrm{d} \\
\text { for } 1 \mathrm{wk} \text { (mean } 114 \mathrm{mg} / \mathrm{d})\end{array}$ & $\begin{array}{l}\text { Primary: Pain intensity* (0-10 NRS) } \\
\text { Secondary: Tolerability of pain, sleep } \\
\text { quality, physical fitness, mental state and } \\
\text { mood, PDI*, symptom complaints }\end{array}$ & $\begin{array}{l}\text { At } 1 \text { wk, } 44 \% \text { under morphine and } 0 \% \text { under } \\
\text { placebo had full responsiveness. After } \\
2 \text { wks, } 40 \% \text { under morphine and } 2 \% \text { under } \\
\text { placebo demonstrated full responsivenss }\end{array}$ \\
\hline \multicolumn{5}{|c|}{ Opioids versus other analgesics } \\
\hline $\begin{array}{l}\text { Gobel and } \\
\text { Stadler (28), } \\
1995 \\
\text { Germany, parallel } \\
\text { (non-EERW) }\end{array}$ & $\begin{array}{l}\text { Postherpetic } \\
\text { neuralgia; } \\
35 \text { (14) }\end{array}$ & $\begin{array}{l}\text { Tramadol 200-600 mg/d for } \\
6 \text { wks } \\
\text { Control: Clomipramine } \\
\text { 50-100 mg/d with or without } \\
\text { levomepromazine } 25-50 \\
\text { mg/d }\end{array}$ & $\begin{array}{l}\text { Primary: Pain intensity* (5-point verbal } \\
\text { rating scale) } \\
\text { Secondary: Psychological and physical } \\
\text { condition }\end{array}$ & $\begin{array}{l}\text { In both groups, the pain intensity decreased } \\
\text { over the } 6 \text { wk treatment period. (Reviewers' } \\
\text { comments: no significant difference between } \\
\text { groups.) There were no essential differences } \\
\text { in the current psychiatric/physical conditions } \\
\text { during tramadol treatment }\end{array}$ \\
\hline $\begin{array}{l}\text { Pavelka et al } \\
\text { (48), } 1998 \\
\text { Czech Republic, } \\
\text { crossover } \\
\text { (non-EERW) }\end{array}$ & $\begin{array}{l}\text { Osteoarthritis hip } \\
\text { and knee; } \\
60(6)\end{array}$ & $\begin{array}{l}\text { Tramadol 150-300 mg/d for } \\
4 \text { wks } \\
\text { Control: Diclofenac } 75-150 \\
\text { mg/d }\end{array}$ & $\begin{array}{l}\text { Primary: WOMAC osteoarthritis index } \\
(\text { pain*, stiffness and physical disability*) } \\
\text { Secondary: Drug preference }\end{array}$ & $\begin{array}{l}\text { Both treatments modestly improved median } \\
\text { pain intensity, parallelled by an } \\
\text { improvement in functional parameters, and } \\
\text { there were no statistically significant } \\
\text { differences between the groups }\end{array}$ \\
\hline $\begin{array}{l}\text { Beaulieu et al } \\
\text { (14), } 2008 \\
\text { Canada, parallel } \\
\text { (non-EERW) }\end{array}$ & $\begin{array}{l}\text { Osteoarthritis knee } \\
\text { or hip; } \\
129(32)\end{array}$ & $\begin{array}{l}\text { CR tramadol } 200-400 / \mathrm{d} \text { for } \\
6 \text { wks } \\
\text { Control: SR diclofenac } \\
75 \mathrm{mg} / \mathrm{d} \text { for } 6 \text { wks }\end{array}$ & $\begin{array}{l}\text { Primary: Daily pain intensity by VAS* and } \\
\text { WOMAC* pain subscale }^{*}\end{array}$ & $\begin{array}{l}\text { Mean change for WOMAC pain subscale } \\
\text { was } 73.2 \pm 99.9 \text { for tramadol and } 80.2 \pm 108 \\
\text { for diclofenac. Mean change for overall } \\
\text { VAS pain score was } 17.3 \pm 22.6 \text { for tramadol } \\
\text { and } 16.4 \pm 24.4 \text { for diclofenac }\end{array}$ \\
\hline $\begin{array}{l}\text { Parr et al (47), } \\
1989 \\
\text { USA, parallel } \\
\text { (non-EERW) }\end{array}$ & $\begin{array}{l}\text { Pain in } \leq 2 \text { joints; } \\
846 \text { (213) }\end{array}$ & $\begin{array}{l}\text { D\&A: Dextropropoxyphene } \\
1080 \mathrm{mg} / \mathrm{d}+ \\
\text { acetaminophen } 1950 \mathrm{mg} / \mathrm{d} \\
\text { for } 4 \mathrm{wks} \\
\text { Control: SR diclofenac } \\
100 \mathrm{mg} / \mathrm{d}\end{array}$ & $\begin{array}{l}\text { Primary: Pain intensity* (100 mm VAS) } \\
\text { Secondary: Nottingham Health Profile } \\
(\mathrm{NHP})^{\star} \text {, energy, sleep, social isolation } \\
\text { and emotional reactions }\end{array}$ & $\begin{array}{l}\text { Pain as measured by VAS showed } 8 \% \\
\text { greater pain reduction with diclofenac } \\
\text { compared with D\&A. Physical mobility as } \\
\text { measured by the NHP improved by } 13 \% \\
\text { more with diclofenac compared with D\&A }\end{array}$ \\
\hline $\begin{array}{l}\text { Salzman and } \\
\text { Brobyn (58), } \\
1983 \\
\text { USA, parallel } \\
\text { (non-EERW) }\end{array}$ & $\begin{array}{l}\text { Osteoarthritis; } \\
57 \text { (11 at } 1 \text { wk) in } \\
\text { Salzman's group } \\
\text { and } 57 \text { ( } 7 \text { at } 1 \text { wk) } \\
\text { in Brobyn's }\end{array}$ & $\begin{array}{l}\text { Propoxyphene } 250 \mathrm{mg} / \mathrm{d} \text { for } \\
24 \text { wks } \\
\text { Control: Suprofen } 800 \mathrm{mg} / \mathrm{d}\end{array}$ & $\begin{array}{l}\text { Primary: Pain intensity* (5-point NRS) } \\
\text { Secondary: Pain relief, global } \\
\text { improvement }\end{array}$ & $\begin{array}{l}\text { Both suprofen and propoxyphene produced } \\
\text { a considerable reduction in pain intensity } \\
\text { from baseline after only } 1 \text { wk of treatment. } \\
\text { This beneficial effect did not diminish with } \\
\text { continued therapy. Further improvement } \\
\text { occurred in both groups by } 24 \text { wks }\end{array}$ \\
\hline
\end{tabular}


TABLE 1 - CONTINUED

Characteristics of the 62 randomized trials included in the present updated systematic review (grouped by type of opioid)

\begin{tabular}{|c|c|c|c|c|}
\hline $\begin{array}{l}\text { Reference, year } \\
\text { Country, design }\end{array}$ & $\begin{array}{l}\text { Population type; } \\
\text { Randomized, n } \\
\text { (dropouts, n) }\end{array}$ & $\begin{array}{l}\text { Interventions and } \\
\text { comparison groups }\end{array}$ & Outcomes: Primary and secondary & Results (as reported in the studies) \\
\hline \multicolumn{5}{|c|}{ Placebo-controlled (mixed pain) } \\
\hline $\begin{array}{l}\text { Glowinski and } \\
\text { Boccard (27), } \\
1999 \\
\text { France, parallel } \\
\text { (non-EERW) }\end{array}$ & $\begin{array}{l}\text { Rheumatoid } \\
\text { arthritis; } \\
60(2)\end{array}$ & $\begin{array}{l}\text { Codeine } 90 \mathrm{mg} / \mathrm{d}+ \\
\text { acetaminophen } 1500 \mathrm{mg} / \mathrm{d} \\
\text { for } 1 \mathrm{wk} \\
\text { Control: Diclofenac } 100 \mathrm{mg} / \mathrm{d} \\
\text { + placebo }\end{array}$ & $\begin{array}{l}\text { Primary: Global efficacy (5-point verbal } \\
\text { scale) } \\
\text { Secondary: Pain intensity* (100 mm VAS), } \\
\text { impairment of activity (4-point scale), } \\
\text { duration of morning stiffness, number of } \\
\text { awakenings }\end{array}$ & $\begin{array}{l}\text { Analgesic efficacy was not significantly } \\
\text { different between the } 2 \text { groups on all } \\
\text { criteria }\end{array}$ \\
\hline
\end{tabular}

Kjaersgaard- Osteoarthritis hip;

Andersen et al $161(64)$

(36), 1990

Denmark, parallel

(non-EERW)

$\begin{array}{ll}\text { Jamison et al } & \text { Back pain; } \\ \text { (33), } 1998 & 36(3) \\ \text { USA, parallel } & \\ \text { (non-EERW) } & \end{array}$

Vlok and Van Osteoarthritis;

Vuren (66), 198731 (3)

South Africa,

crossover

(non-EERW)

Raja et al (52),

2002

Postherpetic neuralgia;

USA, crossover 76 (32)

(non-EERW)

$\begin{array}{ll}\begin{array}{l}\text { Gilron et al (25), } \\ \text { 2005 }\end{array} & \begin{array}{l}\text { neuropathy and } \\ \text { neuric }\end{array} \\ \text { Canada, } & 22 \text { postherpetic } \\ \text { crossover } & \text { neuralgia; } \\ \text { (non-EERW) } & 57(16)\end{array}$

Wu et al (71), 2008

Postamputation pain;

USA, crossover $60(25)$

(non-EERW)

$\begin{array}{cc}\text { Khoromi et al } & \text { Chronic lumbar } \\ \text { (34), 2007 } & \text { radiculopathy } \\ \text { USA, crossover } & \text { (sciatica); } \\ \text { (non-EERW) } & 55(27)\end{array}$

Frank et al (24), Neuropathic pain;

2008

96 (32)

UK, crossover

(non-EERW)
Codeine $180 \mathrm{mg} / \mathrm{d}+$

acetaminophen $3 \mathrm{~g} / \mathrm{d}$ for

4 wks

Control: Acetaminophen $3 \mathrm{~g} / \mathrm{d}$.

Rescue medication:

Ibuprofen tablets $400 \mathrm{mg}$

A. Oxycodone + SR morphine Primary: Pain intensity* (0-100 scale) $90 \mathrm{mg} / \mathrm{d}$ for $16 \mathrm{wks}$ *

Secondary: Mood. Level of activity,

B. SR oxycodone $40 \mathrm{mg} / \mathrm{d}$ for number of hours and amount of study 16 wks. Control: Naproxen medication $1000 \mathrm{mg} / \mathrm{d}$

Codeine $20 \mathrm{mg} / \mathrm{d}+$ ibuprofen Primary: Pain intensity (VAS) $400 \mathrm{mg} / \mathrm{d}+$ acetaminophen Secondary: Pain analogue difference, $500 \mathrm{mg} / \mathrm{d}$ for $4 \mathrm{wks}$ drug choice

Control: Ibuprofen $1200 \mathrm{mg} / \mathrm{d}$

CR morphine up to $240 \mathrm{mg} / \mathrm{d}$ Primary: Pain intensity* (0-10 NRS) for 6 wks. Methadone was an alternative opioid

Control: Nortriptyline up to $160 \mathrm{mg} / \mathrm{d}$. Desipramine was an alternative antidepressant

A. SR morphine maximum tolerated for 5 wks

B. SR morphine maximum tolerated combined with gabapentin for 5 wks

C. Gabapentin maximum tolerated for 5 wks

A. SR morphine 15-180 mg/d Primary: Average change in overall pain for 6 wks

B. Mexiletine: $75-1200 \mathrm{mg} / \mathrm{d}$ for 6 wks intensity from the baseline to the last week of maintenance therapy using 0-10 NRS

Secondary: Pain relief $(0-100 \%)$ and the interference and general activity subscales from the MPI

A. SR morphine 15-90 mg/d Primary: Average leg pain during the

B. Nortriptyline $25-100 \mathrm{mg} / \mathrm{d} \quad 2 \mathrm{wks}$

C. Combination duration: Secondary: Global pain relief, ODI, BDI 9 wks
A. Dihydrocodeine maximum Primary: Difference in pain (VAS)

$240 \mathrm{mg} / \mathrm{d}$ for $14 \mathrm{wks}$

B. Nabilone maximum $2 \mathrm{mg} / \mathrm{d}$ for 14 wks computed over the last 2 wks of each treatment period

Secondary: Change in mood, quality of life (SF-36 role physical)*, sleep and psychometric function
Both opioid groups had significantly less pain and emotional distress than the naproxenonly group. No differences in activity level or hours of sleep were found

Combination of codeine + ibuprofen + acetaminophen was better than ibuprofen alone

The trend favouring opioids over tricyclic antidepressants fell short of significance, and reduction in pain with opioids did not correlate with that following tricyclics

Mean pain intensity at the maximal tolerated dose was 4.49 with placebo, 4.15 with gabapentin, 3.7 with morphine and 3.06 with gabapentin-morphine combination. Total scores in SF-36 were lower with gabapentinmorphine combination than with placebo or each drug alone

Morphine treatment provided lower pain scores compared with placebo and mexiletine. The mean per cent pain relief during treatment with mexiletine, and morphine was $30 \%$ and $53 \%$, respectively

In the 28 of 61 patients who completed the study, none of the treatments produced significant reductions in average leg pain or other leg or back pain scores. Within the limitations of the modest sample size and high dropout rate, these results suggest that nortriptyline, morphine and their combination may have limited effectiveness in the treatment of chronic sciatica

The mean score was $6.0 \mathrm{~mm}$ longer for nabilone than for dihydrocodeine in the available case analysis and $5.6 \mathrm{~mm}$ in the per protocol analysis. Dihydrocodeine provided better pain relief than the synthetic cannabinoid nabilone. Nabilone was significantly superior to dihydrocodeine on the SF-36 (role-physical) 
TABLE 1 - CONTINUED

Characteristics of the 62 randomized trials included in the present updated systematic review (grouped by type of opioid)

\begin{tabular}{|c|c|c|c|c|}
\hline $\begin{array}{l}\text { Reference, year } \\
\text { Country, design }\end{array}$ & $\begin{array}{l}\text { Population type; } \\
\text { Randomized, n } \\
\text { (dropouts, n) }\end{array}$ & $\begin{array}{l}\text { Interventions and } \\
\text { comparison groups }\end{array}$ & Outcomes: Primary and secondary & Results (as reported in the studies) \\
\hline \multicolumn{5}{|c|}{$\mathrm{N}$ of 1 randomized trial } \\
\hline
\end{tabular}

*Data used for meta-analysis. 12-SQ 12-Symptom Questionnaire; ACR American College of Rheumatology; ADL Activity of daily living; AUC Area under the curve; BDI Beck Depression Inventory; bid Twice daily; BPI Brief Pain Inventory; BSS Brief Stress Scale; COX-2 Cyclooxygenase-2; CR Controlled release; CSPI Chronic Pain Sleep Inventory; d Day; DMARD Disease-modifying antirheumatic drug; EERW Enriched enrollment randomized withdrawal; ER Extended release; FMIQ Fibromyalgia Impact Questionnaire; GSS Grip Strength Score; HSCS High Sensitivity Cognitive Screen; IR Immediate release; MPI Multidimensional Pain Inventory; NNT Number needed to treat; NRS Numeric rating scale; NSAID Nonsteroidal anti-inflammatory drug; ODI Oswestry Disability Index; PES Pain Experience Scale; POMS Profile of Mood State; PDI Pain Disability Index; PGI Patient Generated Index; PRRS Pain Relief Rating Scale; PRSS Pain-Related Self-Statement Scale; qid Four times daily; RDQ Roland Disability Questionnaire; RS Ritchie score; SCL-90 Symptom Check List-90; SDS Self-Rating Depression Scale; SF-36 Short Form 36 Health Survey; SF-MPQ Short-Form McGill Pain Questionnaire; SPID-60 Sum of pain intensity differences in the first 60 minutes; SIP Sickness Impact Profile; SR Sustained release; tid Three times daily; VAS Visual analogue scale; WHYMPI West Haven-Yale Multidimensional Pain Inventory. wk Week; WOMAC Western Ontario and McMaster Universities Osteoarthritis Composite Index

\section{TABLE 2}

Efficacy and effectiveness of opioids for chronic noncancer pain

\begin{tabular}{|c|c|c|c|c|}
\hline \multirow[b]{2}{*}{ Efficacy of opioids } & \multicolumn{2}{|c|}{ Pain } & \multicolumn{2}{|c|}{ Function } \\
\hline & Studies, $\mathbf{n}$ & ES $(95 \% \mathrm{Cl})$ & Studies, $\mathbf{n}$ & ES $(95 \% \mathrm{Cl})$ \\
\hline Opioid versus placebo (all types of pain, all designs, all opioids) & 47 & $0.58(0.48$ to 0.67$)$ & 31 & $0.34(0.25$ to 0.43$)$ \\
\hline \multicolumn{5}{|l|}{ Subgroup analysis: EERW design compared with non-EERW design } \\
\hline \multicolumn{5}{|l|}{ Opioid versus placebo } \\
\hline EERW design (all pains, all opioids) & 8 & $0.62(0.33$ to 0.92$)$ & 3 & $0.24(0.08$ to 0.41$)$ \\
\hline Non-EERW design (all pains, all opioids) & 39 & 0.57 (0.47 to 0.67$)$ & 28 & $0.36(0.26$ to 0.45$)$ \\
\hline Fixed effects meta-regression (between EERW and non-EERW) & \multicolumn{2}{|c|}{$P=0.65$} & \multicolumn{2}{|r|}{$P=0.33$} \\
\hline \multicolumn{5}{|l|}{ Subgroup analysis: Weak compared with strong opioid } \\
\hline \multicolumn{5}{|l|}{ Opioid versus placebo } \\
\hline Weak opioids (all pains, all designs) & 22 & 0.55 (0.45 to 0.66$)$ & 15 & $0.31(0.21$ to 0.41$)$ \\
\hline Strong opioids (all pains, all designs) & 25 & $0.60(0.43$ to 0.77$)$ & 16 & $0.37(0.22$ to 0.52$)$ \\
\hline Fixed effects meta-regression (between weak and strong opioids) & \multicolumn{2}{|c|}{$P=0.91$} & \multicolumn{2}{|r|}{$P=0.41$} \\
\hline \multicolumn{5}{|c|}{ Subgroup analyses: Various type of pain (nociceptive, neuropathic, fibromyalgia, mixed) } \\
\hline \multicolumn{5}{|c|}{ Efficacy (opioid compared with placebo) and effectiveness (opioid compared with other drugs) } \\
\hline \multicolumn{5}{|l|}{ Nociceptive pain } \\
\hline Opioid versus placebo & 31 & $0.60(0.49$ to 0.72$)$ & 21 & $0.38(0.26$ to 0.49$)$ \\
\hline Opioid versus nonsteroidal anti-inflammatory drugs & 8 & $0.03(-0.22$ to 0.27$)$ & 3 & $-0.18(-0.31$ to -0.04$)$ \\
\hline Opioid versus acetaminophen & 1 & 0.55 (0.11 to 0.99$)$ & 0 & \\
\hline \multicolumn{5}{|l|}{ Neuropathic pain } \\
\hline Opioid versus placebo & 13 & 0.56 (0.38 to 0.73$)$ & 7 & 0.24 (0.09 to 0.39$)$ \\
\hline Opioid versus tricyclic antidepressant & 3 & $0.15(-0.13$ to 0.43$)$ & 2 & $0.03(-0.26$ to 0.33$)$ \\
\hline Opioid versus anticonvulsant & 1 & $0.19(-0.21$ to 0.59$)$ & 1 & $-0.13(-0.53$ to 0.27$)$ \\
\hline Opioid versus cannabinoid & 1 & 0.62 (0.15 to 1.09$)$ & 1 & $-0.65(-1.16$ to -0.14$)$ \\
\hline \multicolumn{5}{|l|}{ Fibromyalgia } \\
\hline Opioid versus placebo & 2 & 0.41 (0.21 to 0.61$)$ & 2 & 0.33 (0.13 to 0.54$)$ \\
\hline \multicolumn{5}{|l|}{ Mixed pain } \\
\hline Opioid versus placebo & 1 & $0.34(-0.25$ to 0.93$)$ & 1 & $0.35(-0.23$ to 0.94$)$ \\
\hline
\end{tabular}

Effect size (ES): Small (ES $\leq 0.5)$; medium (ES 0.5 to $<0.8$ ); large (ES $\geq 0.8)$. EERW Enriched enrollment randomized withdrawal

Two trials were excluded because they examined the efficacy of opioids for acute-on-chronic pain $(51,63)$. There were 14 trials with an enrichment design: two were excluded from the present review because the patients in both the opioid and the placebo groups received a short-acting opioid for breakthrough pain $(73,74)$ and 12 were included $(18,20,29,37,51,54,56,57,59,60,63,67)$.

From the randomized trials that reported data suitable for metaanalysis, the treatment effect among EERW trials was 0.62 (95\% CI 0.33 to 0.92 ) and was 0.57 (95\% CI 0.47 to 0.67 ) among the 39 non-EERW trials for pain outcomes. The difference between the treatment effects was not statistically significant $(\mathrm{P}=0.6)$. For functional outcomes, there were three EERW (ES=0.24, 95\% CI 0.08 to 0.41 ) and 28 non-EERW trials ( $E S=0.36,95 \% \mathrm{CI} 0.26$ to 0.45$)$. The difference between the treatment effects was not statistically significant $(\mathrm{P}=0.3)$.

Regarding the subgroups of types of pain, the meta-analyses showed a medium ES for pain relief and small ES for functional outcomes for 


\begin{tabular}{|c|c|c|c|c|c|c|c|c|c|c|}
\hline \multirow[b]{3}{*}{ Adverse effects of opioids } & \multicolumn{10}{|c|}{ Randomized trial design } \\
\hline & \multicolumn{5}{|c|}{ Non-EERW } & \multicolumn{5}{|c|}{ EERW } \\
\hline & $\begin{array}{c}\text { Studies, } \\
\mathbf{n}\end{array}$ & $\begin{array}{c}\text { Opioid, } \\
\%\end{array}$ & $\begin{array}{c}\text { Placebo, } \\
\%\end{array}$ & $\begin{array}{l}\text { Difference, } \\
\%(95 \% \mathrm{Cl})\end{array}$ & $\mathbf{P}$ & $\begin{array}{c}\text { Studies, } \\
\mathbf{n}\end{array}$ & $\begin{array}{c}\text { Opioid, } \\
\%\end{array}$ & $\begin{array}{c}\text { Placebo, } \\
\%\end{array}$ & $\begin{array}{l}\text { Difference, } \\
\%(95 \% \mathrm{Cl})\end{array}$ & $\mathbf{P}$ \\
\hline 1. Nausea & 38 & 28 & 9 & 17 (13 to 21$)$ & $<0.00001$ & 5 & 16 & 8 & 7 (0 to 14$)$ & 0.05 \\
\hline 2. Constipation & 37 & 26 & 7 & 20 (15 to 25$)$ & $<0.00001$ & 4 & 15 & 3 & 11 (6 to 16$)$ & $<0.001$ \\
\hline 3. Somnolence/drowsiness & 30 & 24 & 7 & 14 (10 to 18$)$ & $<0.00001$ & 4 & 10 & 5 & 3 (1 to 7$)$ & 0.08 \\
\hline 4. Dizziness/vertigo & 33 & 18 & 5 & 12 (9 to 16$)$ & $<0.00001$ & 3 & 10 & 5 & 5 (2 to 8$)$ & 0.001 \\
\hline 5. Dry skin/itching/pruritus & 25 & 15 & 2 & 10 (5 to 15$)$ & $<0.0001$ & 3 & 5 & 2 & $3(0$ to 5$)$ & 0.05 \\
\hline 6. Vomiting & 23 & 15 & 3 & 11 (7 to 16$)$ & $<0.00001$ & 3 & 2 & 1 & $1(-2$ to 3$)$ & 0.61 \\
\hline 7. Dry mouth & 21 & 12 & 6 & 6 (3 to 9) & $<0.0001$ & & & & & \\
\hline 8. Headache & 28 & 11 & 9 & $1(-1$ to 4$)$ & 0.23 & 4 & 7 & 5 & $1(-2$ to 4$)$ & 0.57 \\
\hline 9. Sexual dysfunction & 1 & 11 & 0 & 11 (-2 to 23$)$ & 0.1 & & & & & \\
\hline 10. Hot flashes & 2 & 10 & 3 & $6(-3$ to 15$)$ & 0.18 & & & & & \\
\hline 11. Loss of appetite & 5 & 10 & 1 & $7(2$ to 13$)$ & 0.004 & & & & & \\
\hline 12. Abdominal pain & 5 & 9 & 4 & $4(-1$ to 10$)$ & 0.11 & & & & & \\
\hline 13. Fatigue & 18 & 9 & 4 & $3(0$ to 7$)$ & 0.04 & & & & & \\
\hline 14. Sleeplessness/insomnia & 10 & 9 & 5 & $4(1$ to 6$)$ & 0.01 & & & & & \\
\hline 15. Sweating & 10 & 8 & 3 & $4(0$ to 7$)$ & 0.03 & & & & & \\
\hline 16. Blurred vision & 5 & 6 & 7 & $1(-2$ to 5$)$ & 0.47 & & & & & \\
\hline 17. Confusion & 5 & 6 & 8 & $-1(-6$ to 4$)$ & 0.76 & & & & & \\
\hline 18. Muscle contractions & 1 & 6 & 3 & $3(-1$ to 6$)$ & 0.19 & & & & & \\
\hline 19. Diarrhea & 14 & 5 & 6 & $-1(-3$ to 1$)$ & 0.3 & 1 & 4 & 5 & $-2(-7$ to 4$)$ & 0.56 \\
\hline 20. Ataxia & 1 & 5 & 0 & 5 (-3 to 12$)$ & 0.23 & & & & & \\
\hline 21. Edema & 1 & 5 & 2 & $2(-5$ to 10$)$ & 0.56 & & & & & \\
\hline 22. Difficulty urinating & 1 & 4 & 0 & $4(-6$ to 13$)$ & 0.45 & & & & & \\
\hline 23. Application site reaction & 1 & 4 & 11 & $-6(-11$ to -1$)$ & 0.01 & & & & & \\
\hline 24. Heartburn & 1 & 4 & 4 & 0 (-10 to 10$)$ & 1 & & & & & \\
\hline 25. Anxiety & 1 & 2 & 0 & $2(-4$ to 8$)$ & 0.46 & & & & & \\
\hline 26. Weakness & 2 & 1 & 3 & $-2(-11$ to 7$)$ & 0.7 & & & & & \\
\hline
\end{tabular}

Bolded data: The difference between opioid and placebo is statistically significant $(P<0.05)$ and clinically relevant (difference $\geq 10 \%)$. EERW Enriched enrollment randomized withdrawal

both nociceptive and neuropathic pain (Table 2). For fibromyalgia and mixed pain, the meta-analyses showed a small ES for both pain and functional outcomes (Table 2).

Effectiveness of opioids compared with other drugs (Table 2) In patients with nociceptive pain, opioids were compared with nonsteroidal anti-inflammatory drugs (NSAIDs) in eight trials reported in seven publications $(14,27,33,47,48,58,66)$ and compared with acetaminophen in one trial (36). A meta-analysis of eight trials of opioids compared with NSAIDS showed no difference for pain outcome. When we assessed the type of opioid used in these trials, seven used a weak opioid (codeine, propoxyphene or tramadol) and one trial used a strong opioid (titrated dose of oxycodone and morphine) (33). When analyzed separately, the meta-analysis of the seven trials of weak opioids did not show that opioids are more effective than NSAIDs, but the strong opioid was shown to be more effective than $1000 \mathrm{mg}$ of naproxen daily. NSAIDs were significantly better than opioids for function, but with a very small ES of 0.18 .

There was only one trial for nociceptive pain comparing codeine plus acetaminophen with acetaminophen alone (36). It was found that at seven days, the addition of codeine was better than providing acetaminophen alone. After this period of time, there was no difference.

In patients with neuropathic pain, opioids were compared with tricyclic antidepressants in three trials $(28,34,52)$, anticonvulsants in one (25) and cannabinoids in one (24). Opioids (either weak or strong) were not more effective than tricyclic antidepressants or anticonvulsants for either pain or function. We found one trial comparing dihydrocodeine with nabilone showing that dihydrocodeine provides better pain relief than nabilone, but the latter was significantly superior to dihydrocodeine on the SF-36 (rolephysical) (24).

\section{Adverse effects}

The incidence of adverse effects was noticeably different in the trials that used a classical non-EERW design from those that used the EERW design (Table 3). Among the trials with a non-EERW design, the number of reported adverse effects was 26, while among the trials with an EERW design, only eight adverse effects were reported. Of the 26 adverse effects reported in the non-EERW design, six achieved a statistically significant and clinically relevant difference: nausea (17\%, $95 \%$ CI $13 \%$ to $21 \%$ ), constipation (20\%, 95\% CI $15 \%$ to $25 \%)$, somnolence/drowsiness (14\%, 95\% CI 10\% to 18\%), dizziness/vertigo (12\%, 95\% CI 9\% to 16\%), dry-skin/itching/pruritus $(10 \%, 95 \%$ CI $5 \%$ to $15 \%)$ and vomiting $(11 \%, 95 \%$ CI $7 \%$ to $16 \%)$. In the trials with an EERW design, only constipation (11\%, 95\% CI $6 \%$ to $16 \%$ ) was found to be statistically significant and clinically relevant.

\section{DISCUSSION}

We identified 62 randomized trials of opioids for a variety of CNCP conditions. Opioids were shown to be effective when compared with placebo in improving pain and function, but the ES were only medium and small, respectively. These conclusions did not change when we analyzed subgroups of EERW/non-EERW design, weak/strong opioids, or when the diagnosis was nociceptive/neuropathic pain.

There is an important difference in side effects reported between EERW and non-EERW designs. Six adverse effects were observed more often in the opioid group than in the placebo group in the non-EERW 
designs. Consumers of opioids should be aware of these effects to make better informed decisions before they are prescribed long-term opioids for CNCP.

All included studies were randomized trials, and the majority were judged to be of high methodological quality. However, most of these trials (74\%) were of short duration (ie, shorter than six weeks), with ties to the pharmaceutical industry and a sizeable number of dropouts. Our analyses could only be performed on what was reported in the trials. On some occasions, we contacted the authors of the trials and were able to clarify some details and obtain more information.

The comparisons of opioids with other drugs were based on studies that were not designed as equivalence or noninferiority trials. Therefore, the conclusions derived from these studies should be accepted with some reservation.

Our conclusions are similar to other recently published systematic reviews on this topic. A recently published Cochrane review of oral or transdermal opioids for osteoarthritis of the knee or hip included 10 trials and concluded that, overall, opioids were more effective than control interventions in terms of pain relief and improvement of function. There were no substantial differences in effects according to type of opioid, analgesic potency (strong or weak), daily dose, duration of treatment or follow-up, methodological quality of trials or type of funding. Adverse events were more frequent in opioid groups compared with controls. They found, however, only small to moderate beneficial effect (75).

Another recent Cochrane review examined the long-term safety, efficacy and effectiveness of opioids for CNCP (76). They included 26 studies with 27 treatment groups, of which 12 were administered orally, five transdermally and 10 intrathecally. Twenty-five of the studies were case series, and there was one randomized trial comparing two opioids. They found that opioids were associated with a clinically significant reduction in pain; however, quality of life and functional status were inconclusive due to insufficient evidence and statistical findings.

More research is needed to determine the usefulness of EERW designs in the administration of opioids for CNCP. In principle, enrichment is a process of increasing the proportion of likely responders to a treatment, and is an efficient strategy for maximizing differences between drug and placebo effects in a clinical trial. Some investigators defend the use of enrichment design in opioids for CNCP because opioids may underperform in clinically heterogeneous contexts, which means that substantial efficacy in a particular subgroup of patient may be diluted or masked by poor efficacy in other subgroups. In the case of opioids, a low proportion of responders would produce an average response that would be moderate at best, concealing the good reponse in the minority of responders; therefore, a drug of potential clinical usefulness to some patients might be discarded because, on average, it did not appear to be very effective in a trial (2). On the other hand, disadvantages of EERW designs include an influence on the apparent efficacy, the limited external validity (generalizability) because of the sample selection procedure, and the invalidation of drug-placebo comparisons because of carryover effects or withdrawal symptoms (77).

There is also a need to assess whether chronic use of opioids provides more benefits than harms in the long-term. None of these randomized trials followed patients for more than one year to determine whether they continued to benefit from opioids.

ACKNOWLEDGEMENTS: The authors acknowledge the support from the National Opioid Use Guideline Group (NOUGG), as well as Quenby Mahood and Joanna Liu, librarians from the Institute for Work $\&$ Health, for their help with the literature searches and article retrieval. Finally, we thank the authors of the randomized trials who responded to our requests for more information while this systematic review was being conducted.
CONTRIBUTORS: All authors participated in the conception and writing of this review. Andrea Furlan was responsible for writing the protocol, and performed the data extraction, quality assessment, statistical analyses and report writing. Luis Chaparro was responsible for the data extraction and quality assessment. Emma Irvin was responsible for the literature searches and writing the methods. Angela Mailis-Gagnon was responsible for overseeing the project and editing the final manuscript.

\section{APPENDIX 1}

Search strategy for MEDLINE

\begin{tabular}{|c|c|c|}
\hline $\begin{array}{l}\text { Search terms for } \\
\text { randomized trials }\end{array}$ & $\begin{array}{l}\text { Search terms for chronic } \\
\text { noncancer pain }\end{array}$ & $\begin{array}{l}\text { Search terms for } \\
\text { opioids }\end{array}$ \\
\hline $\begin{array}{l}\text { 1. randomized } \\
\text { controlled trial.pt. } \\
\text { 2. controlled clinical } \\
\text { trial.pt. }\end{array}$ & $\begin{array}{l}\text { 32. PAIN/pc, dt, rh, th } \\
\text { 33. Chronic Disease/dt, pc, } \\
\text { rh, th } \\
\text { 34. (chronic adj3 pain).mp }\end{array}$ & $\begin{array}{l}\text { 38. exp Analgesics, } \\
\text { opioid/ } \\
\text { 39. Codeine.mp. } \\
\text { 40. Fentanyl.mp. }\end{array}$ \\
\hline $\begin{array}{l}\text { 3. Randomized } \\
\text { Controlled Trials/ } \\
\text { 4. Random Allocation/ }\end{array}$ & $\begin{array}{l}\text { 35. Low Back Pain/ } \\
\text { 36. (low adj back adj } \\
\text { pain).mp }\end{array}$ & $\begin{array}{l}\text { 41. Hydrocodone.mp. } \\
\text { 42. Hydromorphone.mp. } \\
\text { 43. Levorphanol.mp. }\end{array}$ \\
\hline $\begin{array}{l}\text { 5. Double-Blind } \\
\text { Method/ }\end{array}$ & 37. or/ $32-36$ & $\begin{array}{l}\text { 44. Meperidine.mp. } \\
\text { 45. Morphine.mp. }\end{array}$ \\
\hline 6. Single-Blind Method/ & & 46. Oxycodone.mp. \\
\hline 7. or/1-6 & & 47. Oxymorphone.mp. \\
\hline 8. Animal/ not Human/ & & 48. Pentazocine.mp. \\
\hline 9. 7 not 8 & & 49. Propoxyphene.mp. \\
\hline 10. clinical trial.pt. & & 50. Sufentanil.mp. \\
\hline 11. explode Clinical & & 51. Tramadol.mp \\
\hline $\begin{array}{l}\text { Trials/ } \\
12 \text { (clinic } \$ \text { adi25 trial\$) }\end{array}$ & & 52. or/ 38-51 \\
\hline
\end{tabular}

tw.

13. ( $($ singl\$ or doubl\$ or

trebl\$or tripl\$)

$\operatorname{adj}(\operatorname{mask} \$$ or

blind\$)).tw.

14. Placebos/

15. placebo\$.tw.

16. random $\$$.tw.

17. Research Design/

18. (latin adj square).tw.

19. or/10-18

20. 19 not 8

21. 20 not 9

22. Comparative Study/

23. explode Evaluation Studies/

24. Follow-Up Studies/

25. Prospective Studies/

26. (control\$ or prospectiv\$ or volunteer\$).tw.

27. Cross-Over Studies/

28. or/22-27

29. 28 not 8

30. 29 not ( 9 or 21$)$

31. 9 or 21 or 30

Combining all searches

53. 31 and 37 and 52

dt Drug therapy; Exp Explode; mp Multipurpose; pc Prevention and control; Pt Publication type; rh Rehabilitation; th Therapy; tw Text word 


\section{APPENDIX 2}

\section{Search strategy for EMBASE}

\begin{tabular}{|c|c|c|}
\hline $\begin{array}{l}\text { Search terms for randomized } \\
\text { controlled trials }\end{array}$ & $\begin{array}{l}\text { Search terms for } \\
\text { chronic noncancer } \\
\text { pain }\end{array}$ & $\begin{array}{l}\text { Search terms for } \\
\text { opioids }\end{array}$ \\
\hline 1. Randomized Controlled Trial/ & 43. Pain/pc, rh, dt, th & 49. exp Narcotic \\
\hline $\begin{array}{l}\text { 2. (random: adj2 control: } \\
\text { trial:).mp. }\end{array}$ & $\begin{array}{l}\text { 44. Chronic Disease/ } \\
\text { pc, rh, dt, th }\end{array}$ & $\begin{array}{l}\text { Analgesic Agent/ } \\
\text { 50. Codeine.mp. }\end{array}$ \\
\hline 3. 1 or 2 & 45. (chronic adj3 & 51. Fentanyl.mp. \\
\hline 4. control: clinical trial:.mp. & pain).mp. & 52. Hydromorphone. \\
\hline 5. (control: adj2 trial:).mp. & 46. Low Back Pain/ & $\mathrm{mp}$ \\
\hline 6.4 or 5 & 47. (low adj back adj & 53. Levorphanol.mp. \\
\hline 7. randomization/ & pain).mp. & 54. Meperidine.mp. \\
\hline 8. random: allocation:.mp. & 48. or/43-47 & 55. Morphine.mp. \\
\hline 9. (random: adj2 allocation:).mp. & & 56. Oxycodone.mp. \\
\hline 10. 8 or 9 & & 57. Oxymorphone. \\
\hline 11. Double Blind Procedure/ & & \\
\hline 12. double-blind method:.mp. & & 58. Pentazocine.mp. \\
\hline 13. Single Blind Procedure/ & & 59. Propoxyphene. \\
\hline 14. single-blind method:.mp. & & \\
\hline 15. or/1-14 & & 60. Tramadol. \\
\hline $\begin{array}{l}\text { 16. limit } 15 \text { to (amphibia or ape or } \\
\text { bird or cat or cattle or chicken }\end{array}$ & & $\begin{array}{l}\text { mp.sufentanil. } \\
\mathrm{mp}\end{array}$ \\
\hline or dog or "ducks and geese" & & 61. Tramadol.mp \\
\hline $\begin{array}{l}\text { or fish or "frogs and toads" or } \\
\text { goat or guinea pig or } \\
\text { "hamsters and gerbils" or } \\
\text { horse or monkey or mouse or } \\
\text { "pigeons and doves" or } \\
\text { "rabbits and hares" or rat or } \\
\text { reptile or sheep or swine) }\end{array}$ & & 62. or/49-61 \\
\hline \multicolumn{3}{|l|}{ 17. exp animal/ } \\
\hline \multicolumn{3}{|l|}{ 18. 15 and 17} \\
\hline \multicolumn{3}{|l|}{ 19. 16 or 18} \\
\hline \multicolumn{3}{|l|}{ 20. limit 15 to human } \\
\hline \multicolumn{3}{|l|}{ 21. 20 not 19} \\
\hline \multicolumn{3}{|l|}{ 22. Clinical Trial/ } \\
\hline \multicolumn{3}{|l|}{ 23. exp clinical trial/ } \\
\hline \multicolumn{3}{|l|}{ 24. (clinic: adj25 trial:).tw. } \\
\hline \multicolumn{3}{|l|}{$\begin{array}{l}\text { 25. ((singl: or doubl: or trebl: or } \\
\text { tripl:) adj (mask: or blind:)).tw. }\end{array}$} \\
\hline \multicolumn{3}{|l|}{ 26. PLACEBO/ } \\
\hline \multicolumn{3}{|l|}{ 27. placebo:.mp. } \\
\hline \multicolumn{3}{|l|}{ 28. random:.tw. } \\
\hline \multicolumn{3}{|l|}{ 29. methodology/ } \\
\hline \multicolumn{3}{|l|}{ 30. latin square design/ } \\
\hline \multicolumn{3}{|l|}{ 31. (latin adj square). tw. } \\
\hline \multicolumn{3}{|l|}{ 32. or/22-31 } \\
\hline \multicolumn{3}{|l|}{ 33. 32 not 19} \\
\hline \multicolumn{3}{|l|}{ 34. Comparative Study/ } \\
\hline \multicolumn{3}{|l|}{ 35. evaluation/ } \\
\hline \multicolumn{3}{|l|}{ 36. follow up/ } \\
\hline \multicolumn{3}{|l|}{ 37. prospective study/ } \\
\hline \multicolumn{3}{|l|}{$\begin{array}{l}\text { 38. (control: or prospectiv: or } \\
\text { volunteer:).tw. }\end{array}$} \\
\hline \multicolumn{3}{|l|}{ 39. Crossover Procedure/ } \\
\hline \multicolumn{3}{|l|}{ 40. or/34-39 } \\
\hline \multicolumn{3}{|l|}{ 41. 40 not 19} \\
\hline 42. 21 or 33 or 41 & & \\
\hline
\end{tabular}

Combining all searches

63. 42 and 48 and 62

dt Drug therapy; Exp Explode; mp Multipurpose; $p c$ Prevention and control; Pt Publication type; rh Rehabilitation; th Therapy; tw Text word
APPENDIX 3

The Cochrane Collaboration's tool for assessing risk of bias (7)

\begin{tabular}{|c|c|c|}
\hline Domain & Description & $\begin{array}{l}\text { Review authors' } \\
\text { judgement }\end{array}$ \\
\hline Sequence generation & $\begin{array}{l}\text { Describe the method used to } \\
\text { generate the allocation } \\
\text { sequence in sufficient detail to } \\
\text { allow an assessment of } \\
\text { whether it should produce } \\
\text { comparable groups }\end{array}$ & $\begin{array}{l}\text { Was the allocation } \\
\text { sequence } \\
\text { adequately } \\
\text { generated? }\end{array}$ \\
\hline $\begin{array}{l}\text { Allocation } \\
\text { concealment }\end{array}$ & $\begin{array}{l}\text { Describe the method used to } \\
\text { conceal the allocation } \\
\text { sequence in sufficient detail to } \\
\text { determine whether intervention } \\
\text { allocations could have been } \\
\text { foreseen in advance of, or } \\
\text { during, enrollment }\end{array}$ & $\begin{array}{l}\text { Was allocation } \\
\text { adequately } \\
\text { concealed? }\end{array}$ \\
\hline $\begin{array}{l}\text { Blinding of } \\
\text { participants, } \\
\text { personnel and } \\
\text { outcome assessors: } \\
\text { Assessments should } \\
\text { be made for each } \\
\text { main outcome (or } \\
\text { class of outcomes) }\end{array}$ & $\begin{array}{l}\text { Describe all measures used, if } \\
\text { any, to blind study participants } \\
\text { and personnel from knowledge } \\
\text { of which intervention a } \\
\text { participant received. Provide } \\
\text { any information relating to } \\
\text { whether the intended blinding } \\
\text { was effective }\end{array}$ & $\begin{array}{l}\text { Was knowledge of } \\
\text { the allocated } \\
\text { intervention } \\
\text { adequately } \\
\text { prevented during } \\
\text { the study? }\end{array}$ \\
\hline $\begin{array}{l}\text { Incomplete outcome } \\
\text { data: } \\
\text { Assessments should } \\
\text { be made for each } \\
\text { main outcome (or } \\
\text { class of outcomes) }\end{array}$ & $\begin{array}{l}\text { Describe the completeness of } \\
\text { outcome data for each main } \\
\text { outcome, including attrition } \\
\text { and exclusions from the } \\
\text { analysis. State whether } \\
\text { attrition and exclusions were } \\
\text { reported, the numbers in each } \\
\text { intervention group (compared } \\
\text { with total randomized } \\
\text { participants), reasons for } \\
\text { attrition/exclusions where } \\
\text { reported, and any re-inclusions } \\
\text { in analyses performed by the } \\
\text { review authors }\end{array}$ & $\begin{array}{l}\text { Were incomplete } \\
\text { outcome data } \\
\text { adequately } \\
\text { addressed? }\end{array}$ \\
\hline $\begin{array}{l}\text { Selective outcome } \\
\text { reporting }\end{array}$ & $\begin{array}{l}\text { State how the possibility of } \\
\text { selective outcome reporting } \\
\text { was examined by the review } \\
\text { authors, and what was found }\end{array}$ & $\begin{array}{l}\text { Are reports of the } \\
\text { study free of } \\
\text { suggestion of } \\
\text { selective outcome } \\
\text { reporting? }\end{array}$ \\
\hline Other sources of bias & $\begin{array}{l}\text { State any important concerns } \\
\text { about bias not addressed in } \\
\text { the other domains in the tool. } \\
\text { If particular questions/entries } \\
\text { were prespecified in the } \\
\text { review's protocol, responses } \\
\text { should be provided for each } \\
\text { question/entry }\end{array}$ & $\begin{array}{l}\text { Was the study } \\
\text { apparently free of } \\
\text { other problems } \\
\text { that could put it at } \\
\text { a high risk of } \\
\text { bias? }\end{array}$ \\
\hline
\end{tabular}

\section{REFERENCES}

1. Straube S, Derry S, McQuay HJ, Moore RA. Enriched enrollment: Definition and effects of enrichment and dose in trials of pregabalin and gabapentin in neuropathic pain. A systematic review. Br J Clin Pharmacol 2008;66:266-75.

2. McQuay HJ, Derry S, Moore RA, Poulain P, Legout V. Enriched enrolment with randomised withdrawal (EERW): Time for a new look at clinical trial design in chronic pain. Pain 2008;135:217-20.

3. Staud R, Price DD. Long-term trials of pregabalin and duloxetine for fibromyalgia symptoms: How study designs can affect placebo factors. Pain 2008;136:232-4.

4. Furlan AD, Sandoval JA, Mailis-Gagnon A, Tunks E. Opioids for chronic noncancer pain: A meta-analysis of effectiveness and side effects. CMAJ 2006;174:1589-94. 
5. Furlan AD, Reardon R, Weppler C. Opioids for chronic noncancer pain: A new Canadian practice guideline. CMAJ 2010;182:923-30.

6. Repchinsky C. Table 2: Opioid Analgesics. Approximate analgesic equivalences. Compendium of Pharmaceutical Specialties. Ottawa: Canadian Pharmacists Association, 2004:457.

7. Higgins JPT, Green S. Assessing risk of bias in included studies. In: Higgins JPT, Altman DG, eds. Cochrane Handbook for Systematic Reviews of Interventions. The Cochrane Collaboration, 2008.

8. Cohen J. Statistical power analysis for the behavioral sciences. New York, San Francisco, London: Academic Press, 1988.

9. Kosinski M, Janagap C, Gajria K, Schein J, Freedman J. Pain relief and pain-related sleep disturbance with extended-release tramadol in patients with osteoarthritis. Curr Med Res Opin 2007:23:1615-26.

10. Gana TJ, Pascual ML, Fleming RR, et al. Extended-release tramadol in the treatment of osteoarthritis: A multicenter, randomized, double-blind, placebo-controlled clinical trial. Curr Med Res Opin 2006;22:1391-401.

11. Schein JR, Kosinski MR, Janagap-Benson C, Gajria K, Lin P, Freedman JD. Functionality and health-status benefits associated with reduction of osteoarthritis pain. Curr Med Res Opin 2008;24:1255-65.

12. Arkinstall W, Sandler A, Goughnour B, Babul N, Harsanyi Z, Darke AC. Efficacy of controlled-release codeine in chronic non-malignant pain: A randomized, placebo-controlled clinical trial. Pain 1995;62:169-78.

13. Babul N, Noveck R, Chipman H, Roth SH, Gana T, Albert K. Efficacy and safety of extended-release, once-daily tramadol in chronic pain: A randomized 12-week clinical trial in osteoarthritis of the knee. J Pain Symptom Manage 2004;28:59-71.

14. Beaulieu AD, Peloso PM, Haraoui B, et al. Once-daily, controlled-release tramadol and sustained-release diclofenac relieve chronic pain due to osteoarthritis: A randomized controlled trial. Pain Res Manag 2008;13:103-10.

15. Bennett RM, Kamin M, Karim R, Rosenthal N. Tramadol and acetaminophen combination tablets in the treatment of fibromyalgia pain: A double-blind, randomized, placebo-controlled study. Am J Med 2003;114:537-45.

16. Boureau F, Boccard E. Placebo-controlled study of analgesic efficacy of $500 \mathrm{mg}$ paracetamol $30 \mathrm{mg}$ codeine association combined with a low dose of diclofenac versus high dose of diclofenac in rheumatoid arthritis. Acta Therapeutica 1991;17:123-36.

17. Boureau F, Legallicier P, Kabir-Ahmadi M. Tramadol in post-herpetic neuralgia: A randomized, double-blind, placebo-controlled trial. Pain 2003;104:323-31.

18. Burch F, Fishman R, Messina N, et al. A comparison of the analgesic efficacy of Tramadol Contramid OAD versus placebo in patients with pain due to osteoarthritis. J Pain Symptom Manage 2007;34:328-38.

19. Caldwell JR, Rapoport RJ, Davis JC, et al. Efficacy and safety of a once-daily morphine formulation in chronic, moderate-to-severe osteoarthritis pain: Results from a randomized, placebo-controlled, double-blind trial and an open-label extension trial. J Pain Symptom Manage 2002;23:278-91.

20. Caldwell JR, Hale ME, Boyd RE, et al. Treatment of osteoarthritis pain with controlled release oxycodone or fixed combination oxycodone plus acetaminophen added to nonsteroidal antiinflammatory drugs: A double blind, randomized, multicenter, placebo controlled trial. J Rheumatol 1999;26:862-9.

21. Chindalore VL, Craven RA, Yu KP, Butera PG, Burns LH, Friedmann N. Adding ultralow-dose naltrexone to oxycodone enhances and prolongs analgesia: A randomized, controlled trial of Oxytrex. J Pain 2005;6:392-9.

22. Emkey R, Rosenthal N, Wu S-C, Jordan D, Kamin M. Efficacy and safety of tramadol/acetaminophen tablets (Ultracet) as add-on therapy for osteoarthritis pain in subjects receiving a COX-2 nonsteroidal antiinflammatory drug: A multicenter, randomized, double-blind, placebo-controlled trial. J Rheumatol 2004;31:150-6.

23. Fleischmann RM, Caldwell JR, Roth SH, et al. Tramadol for the treatment of joint pain associated with osteoarthritis: A randomized, double-blinded, placebo-controlled trial. Curr Ther Res 2001;62:113-28.

24. Frank B, Serpell MG, Hughes J, Matthews JN, Kapur D. Comparison of analgesic effects and patient tolerability of nabilone and dihydrocodeine for chronic neuropathic pain: Randomised, crossover, double blind study. BMJ 2008;336:199-201.
25. Gilron I, Bailey JM, Tu D, Holden RR, Weaver DF, Houlden RL. Morphine, gabapentin, or their combination for neuropathic pain. N Engl J Med 2005;352:1324-34.

26. Gimbel JS, Richards P, Portenoy RK. Controlled-release oxycodone for pain in diabetic neuropathy: A randomized controlled trial. Neurology 2003;60:927-34.

27. Glowinski J, Boccard E. Placebo-controlled study of the analgesic efficacy of a paracetamol $500 \mathrm{mg} /$ codeine $30 \mathrm{mg}$ combination together with low-dose vs high-dose diclofenac in rheumatoid arthritis. Clin Drug Investig 1999;18:189-97.

28. Gobel H, Stadler TH. Treatment of pain due to postherpetic neuralgia with tramadol. Results of an open, parallel pilot study vs clomipramine with and without levomepromazine. Clin Drug Investig 1995;10:208-14.

29. Hale ME, Ahdieh H, Ma T, Rauck R. Efficacy and safety of OPANA ER (Oxymorphone Extended Release) for relief of moderate to severe chronic low back pain in opioid-experienced patients: A 12-week, randomized, double-blind, placebo-controlled study. J Pain 2007;8:175-84

30. Harati Y, Gooch C, Swenson M, et al. Double-blind randomized trial of tramadol for the treatment of the pain of diabetic neuropathy. Neurology 1998;50:1842-6.

31. Harke H, Gretenkort P, Ladleif HU, Rahman S, Harke O. The response of neuropathic pain and pain in complex regional pain syndrome I to carbamazepine and sustained-release morphine in patients pretreated with spinal cord stimulation: A double-blinded randomized study. Anesth Analg 2001;92:488-95.

32. Huse E, Larbig W, Flor H, Birbaumer N. The effect of opioids on phantom limb pain and cortical reorganization. Pain 2001;90:47-55.

33. Jamison RN, Raymond SA, Slawsby EA, Nedeljkovic SS, Katz NP. Opioid therapy for chronic noncancer back pain. A randomized prospective study. Spine 1998;23:2591-600.

34. Khoromi S, Cui L, Nackers L, Max MB. Morphine, nortriptyline and their combination vs. placebo in patients with chronic lumbar root pain. Pain 2007;130:66-75.

35. Kivitz A, Ma C, Ahdieh H, Galer BS. A 2-week, multicenter, randomized, double-blind, placebo-controlled, dose-ranging, phase III trial comparing the efficacy of oxymorphone extended release and placebo in adults with pain associated with osteoarthritis of the hip or knee. Clin Ther 2006;28:352-64.

36. Kjaersgaard-Andersen P, Nafei A, Skov O, et al. Codeine plus paracetamol versus paracetamol in longer-term treatment of chronic pain due to osteoarthritis of the hip. A randomised, double-blind, multi-centre study. Pain 1990;43:309-18.

37. Landau CJ, Carr WD, Razzetti AJ, Sessler NE, Munera C, Ripa SR. Buprenorphine transdermal delivery system in adults with persistent noncancer-related pain syndromes who require opioid therapy: A multicenter, 5-week run-in and randomized, double-blind maintenance-of-analgesia study. Clin Ther 2007;29:2179-93

38. Langford R, McKenna F, Ratcliffe S, Vojtassak J, Richarz U. Transdermal fentanyl for improvement of pain and functioning in osteoarthritis: A randomized, placebo-controlled trial. Arthritis Rheum 2006;54:1829-37.

39. Lee EY, Lee EB, Park BJ, et al. Tramadol 37.5-mg/acetaminophen 325 -mg combination tablets added to regular therapy for rheumatoid arthritis pain: A 1-week, randomized, double-blind, placebo-controlled trial. Clin Ther 2006;28:2052-60.

40. Ma K, Jiang W, Zhou Q, Du DP. The efficacy of oxycodone for management of acute pain episodes in chronic neck pain patients. Int J Clin Pract 2008;62:241-7.

41. Maier C, Hildebrandt J, Klinger R, Henrich-Eberl C, Lindena G; MONTAS Study Group. Morphine responsiveness, efficacy and tolerability in patients with chronic non-tumor associated pain results of a double-blind placebo-controlled trial (MONTAS). Pain 2002;97:223-33.

42. Markenson JA, Croft J, Zhang PG, Richards P. Treatment of persistent pain associated with osteoarthritis with controlled-release oxycodone tablets in a randomized controlled clinical trial. Clin J Pain 2005;21:524-35.

43. Matsumoto AK, Babul N, Ahdieh H. Oxymorphone extended-release tablets relieve moderate to severe pain and improve physical function in osteoarthritis: Results of a randomized, double-blind, placebo- and active-controlled phase III trial. Pain Med 2005;6:357-66.

44. Moran C. MST continuous tablets and pain control in severe rheumatoid arthritis. Br J Clin Res 1991;2:1-12. 
45. Moulin DE, Iezzi A, Amireh R, Sharpe WK, Boyd D, Merskey H. Randomised trial of oral morphine for chronic non-cancer pain. Lancet 1996;347:143-7.

46. Norrbrink C, Lundeberg T. Tramadol in neuropathic pain after spinal cord injury: A randomized, double-blind, placebo-controlled trial. Clin J Pain 2009;25:177-84.

47. Parr G, Darekar B, Fletcher A, Bulpitt CJ. Joint pain and quality of life; results of a randomised trial. $\mathrm{Br} \mathrm{J}$ Clin Pharmacol 1989;27:235-42.

48. Pavelka K, Peliskova Z, Stehlikova H, Ratcliffe S, Repas C. Intraindividual differences in pain relief and functional improvement in osteoarthritis with diclofenac or tramadol. Clin Drug Investig 1998;16:421-9.

49. Peloso PM, Fortin L, Beaulieu A, Kamin M, Rosenthal N. Analgesic efficacy and safety of tramadol/acetaminophen combination tablets (Ultracet) in treatment of chronic low back pain: A multicenter, outpatient, randomized, double blind, placebo controlled trial. J Rheumatol 2004;31:2454-63.

50. Peloso PM, Bellamy N, Bensen W, et al. Double blind randomized placebo control trial of controlled release codeine in the treatment of osteoarthritis of the hip or knee. J Rheumatol 2000;27:764-71.

51. Portenoy RK, Messina J, Xie F, Peppin J. Fentanyl buccal tablet (FBT) for relief of breakthrough pain in opioid-treated patients with chronic low back pain: A randomized, placebo-controlled study. Curr Med Res Opin 2007;23:223-33.

52. Raja SN, Haythornthwaite JA, Pappagallo M, et al. Opioids versus antidepressants in postherpetic neuralgia: A randomized, placebo-controlled trial. Neurology 2002;59:1015-21.

53. Roth SH, Fleischmann RM, Burch FX, et al. Around-the-clock, controlled-release oxycodone therapy for osteoarthritis-related pain: Placebo-controlled trial and long-term evaluation. Arch Intern Med 2000;160:853-60.

54. Roth SH. Efficacy and safety of tramadol $\mathrm{HCl}$ in breakthrough musculoskeletal pain attributed to osteoarthritis. J Rheumatol 1998;25:1358-63.

55. Ruoff GE. Slowing the initial titration rate of tramadol improves tolerability. Pharmacotherapy 1999;19:88-93.

56. Ruoff GE, Rosenthal N, Jordan D, Karim R, Kamin M; Protocol CAPS. Tramadol/acetaminophen combination tablets for the treatment of chronic lower back pain: A multicenter, randomized, double-blind, placebo-controlled outpatient study. Clin Ther 2003;25:1123-41.

57. Russell J, Kamin M, Bennett RM, Schnitzer TJ, Green JA, Katz WA. Efficacy of tramadol in treatment of pain in fibromyalgia. J Clin Rheumatol 2000;6:250-7.

58. Salzman RT, Brobyn RD. Long-term comparison of suprofen and propoxyphene in patients with osteoarthritis. Pharmacology 1983;27(Suppl 1):55-64.

59. Schnitzer TJ, Gray WL, Paster RZ, Kamin M. Efficacy of tramadol in treatment of chronic low back pain. J Rheumatol 2000;27:772-8. (Comment)

60. Schnitzer TJ, Kamin M, Olson WH. Tramadol allows reduction of naproxen dose among patients with naproxen-responsive osteoarthritis pain: A randomized, double-blind, placebo-controlled study. Arthritis Rheum 1999;42:1370-7.

61. Sheather-Reid RB, Cohen M. Efficacy of analgesics in chronic pain: A series of N-of-1 studies. J Pain Symptom Manage 1998;15:244-52.
62. Silverfield JC, Kamin M, Wu SC, Rosenthal N; CAPSS-105 Study Group. Tramadol/acetaminophen combination tablets for the treatment of osteoarthritis flare pain: A multicenter, outpatient, randomized, double-blind, placebo-controlled, parallel-group, add-on study. Clin Ther 2002;24:282-97.

63. Simpson DM, Messina J, Xie F, Hale M. Fentanyl buccal tablet for the relief of breakthrough pain in opioid-tolerant adult patients with chronic neuropathic pain: A multicenter, randomized, double-blind, placebo-controlled study. Clin Ther 2007;29:588-601.

64. Sindrup SH, Andersen G, Madsen C, Smith T, Brosen K, Jensen TS. Tramadol relieves pain and allodynia in polyneuropathy: A randomised, double-blind, controlled trial. Pain 1999;83:85-90.

65. Thorne C, Beaulieu AD, Callaghan DJ, et al. A randomized, double-blind, crossover comparison of the efficacy and safety of oral controlled-release tramadol and placebo in patients with painful osteoarthritis. Pain Res Manag 2008;13:93-102.

66. Vlok GJ, van Vuren JP. Comparison of a standard ibuprofen treatment regimen with a new ibuprofen/paracetamol/codeine combination in chronic osteo-arthritis. S Afr Med J 1987;(Suppl 1):4-6.

67. Vorsanger GJ, Xiang J, Gana TJ, Pascual ML, Fleming RR. Extended-release tramadol (tramadol ER) in the treatment of chronic low back pain. J Opioid Manag 2008;4:87-97.

68. Watson CP, Moulin D, Watt-Watson J, Gordon A, Eisenhoffer J. Controlled-release oxycodone relieves neuropathic pain: A randomized controlled trial in painful diabetic neuropathy. Pain 2003;105:71-8.

69. Watson CP, Babul N. Efficacy of oxycodone in neuropathic pain: A randomized trial in postherpetic neuralgia. Neurology 1998;50:1837-41.

70. Webster LR, Butera PG, Moran LV, Wu N, Burns LH, Friedmann N. Oxytrex minimizes physical dependence while providing effective analgesia: A randomized controlled trial in low back pain 418. J Pain 2006;7:937-46.

71. Wu CL, Agarwal S, Tella PK, et al. Morphine versus mexiletine for treatment of postamputation pain: A randomized, placebo-controlled, crossover trial. Anesthesiology 2008;109:289-96.

72. Zautra AJ, Smith BW. Impact of controlled-release oxycodone on efficacy beliefs and coping efforts among osteoarthritis patients with moderate to severe pain. Clin J Pain 2005;21:471-7.

73. Katz N, Rauck R, Ahdieh H, et al. A 12-week, randomized, placebo-controlled trial assessing the safety and efficacy of oxymorphone extended release for opioid-naive patients with chronic low back pain. Curr Med Res Opin 2007;23:117-28.

74. Vondrackova D, Leyendecker P, Meissner W, et al. Analgesic efficacy and safety of oxycodone in combination with naloxone as prolonged release tablets in patients with moderate to severe chronic pain. J Pain 2008;9:1144-54.

75. Nuesch E, Rutjes AW, Husni E, Welch V, Juni P. Oral or transdermal opioids for osteoarthritis of the knee or hip. Cochrane Database Syst Rev 2009;(4):CD003115.

76. Noble M, Treadwell JR, Tregear SJ, et al. Long-term opioid management for chronic noncancer pain. Cochrane Database Syst Rev 2010;(1):CD006605.

77. Leber PD, Davis CS. Threats to the validity of clinical trials employing enrichment strategies for sample selection. Control Clin Trials 1998;19:178-87. 


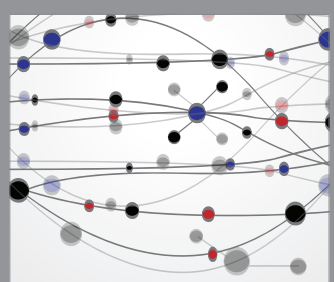

The Scientific World Journal
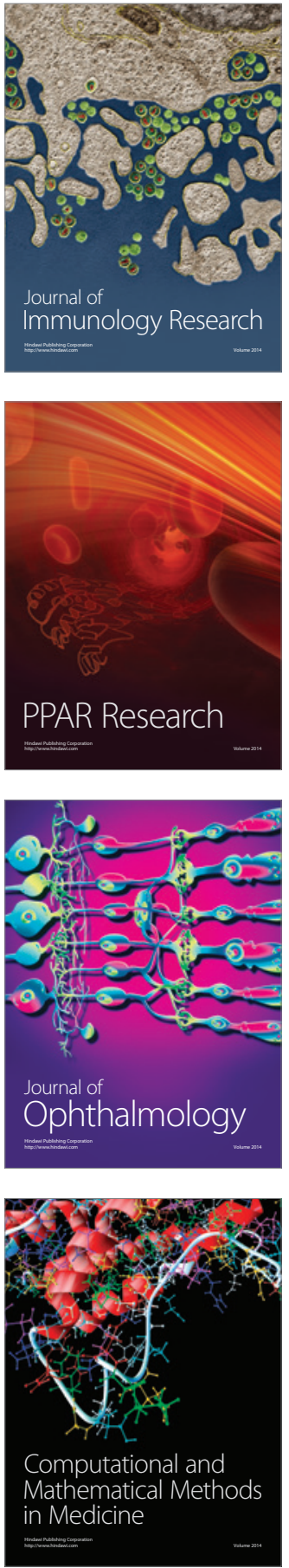

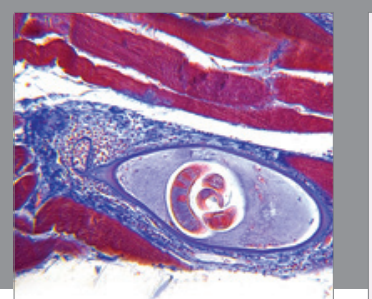

Gastroenterology Research and Practice

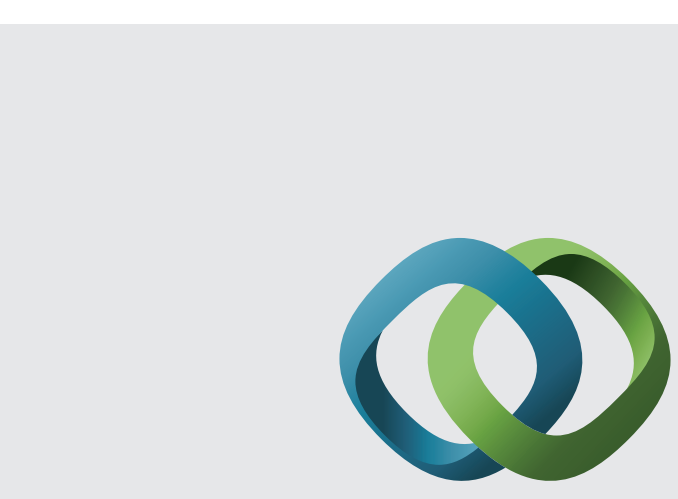

\section{Hindawi}

Submit your manuscripts at

http://www.hindawi.com
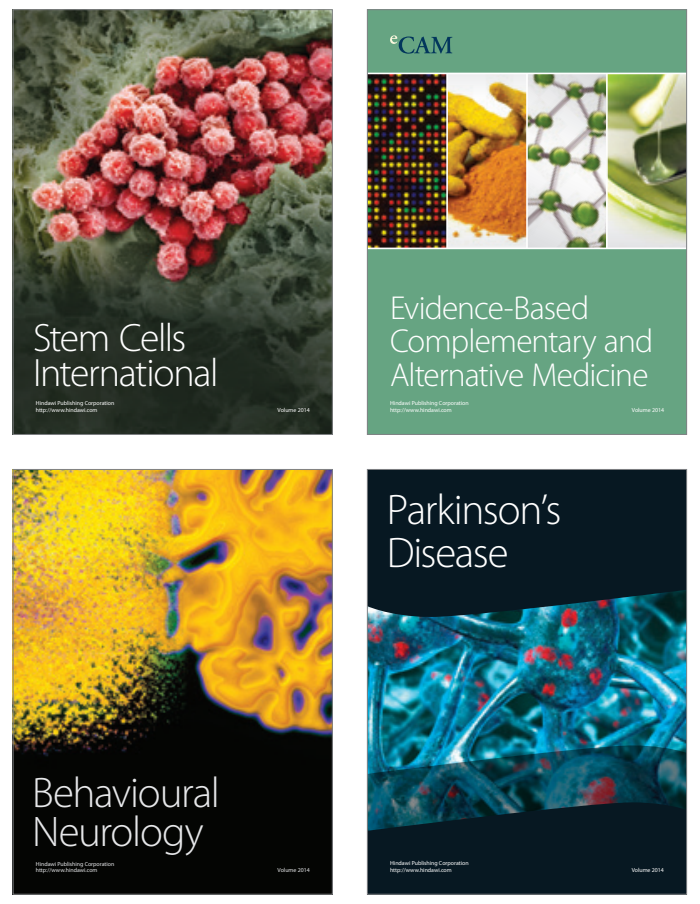
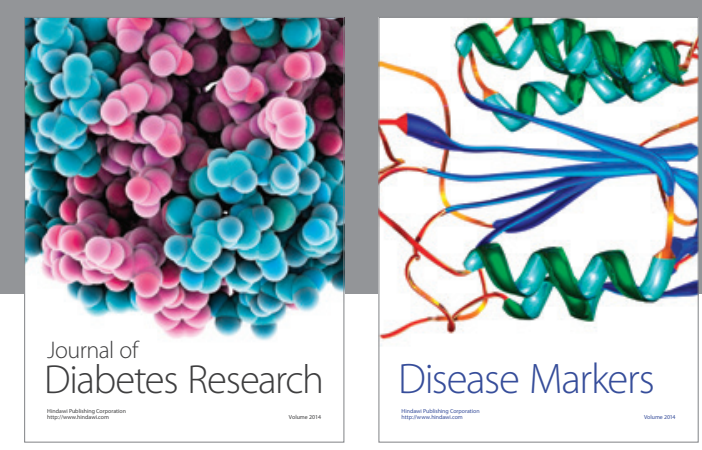

Disease Markers
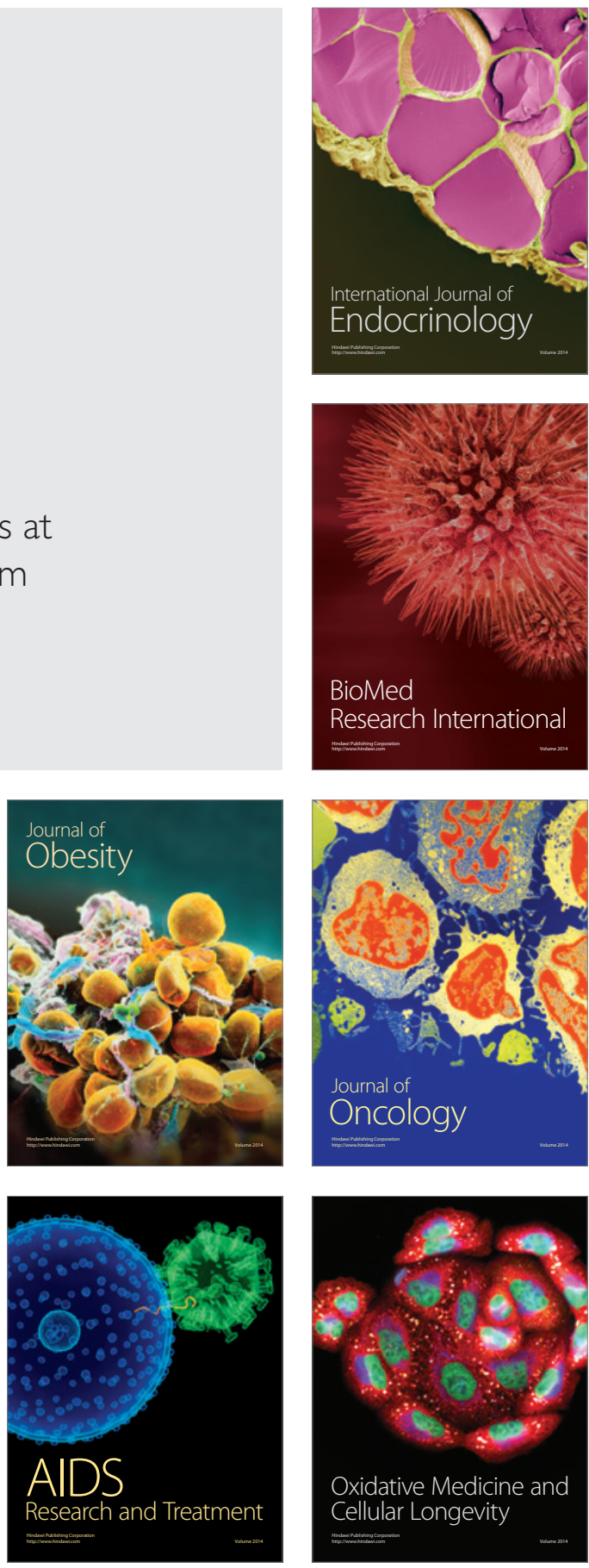